\title{
Grandmaternal allergen exposure causes distinct epigenetic trajectories in offspring associated with airway hyperreactivity and inflammation.
}

Katie M. Lebold ${ }^{1}$ and Madeline Cook ${ }^{2}$, Alexandra B. Pincus ${ }^{2}$, Kimberly A. Nevonen ${ }^{3}$, Brett A. Davis ${ }^{3}$, Lucia Carbone ${ }^{3,4}$, Gina N. Calco², Allison D. Fryer ${ }^{2}$, David B. Jacoby², Matthew $G$. Drake ${ }^{\star 2}$

\section{Affiliations:}

${ }^{1}$ Department of Emergency Medicine, Stanford University School of Medicine, Palo Alto, California

${ }^{2}$ Division of Pulmonary and Critical Care Medicine, Department of Medicine, Oregon Health and Science University, Portland, Oregon.

${ }^{3}$ Knight Cardiovascular Institute Epigenetics Consortium, Oregon Health and Science University, Portland, Oregon

${ }^{4}$ Departments of Medicine, Molecular and Medical Genetics, and Medical Informatics and Clinical Epidemiology, Oregon Health and Science University, Portland, Oregon.

${ }^{*}$ Correspondence to: Matthew Drake, MD.

OHSU Division of Pulmonary and Critical Care Medicine

3181 SW Sam Jackson Park Rd

Mail Code UHN67

Portland, OR 97239

Phone: 503-418-1227

drakem@ohsu.edu

ORCID ID: 0000-0001-5476-0361 


\section{SUMMARY}

Grandmaternal allergen exposure establishes an intergenerational, tissue-specific epigenetic trajectory in offspring at birth, which uniquely directs responses to allergen sensitization and challenge later in life and contributes to inheritance of asthma risk. 
bioRxiv preprint doi: https://doi.org/10.1101/2022.01.25.477760; this version posted January 27, 2022. The copyright holder for this preprint (which was not certified by peer review) is the author/funder. All rights reserved. No reuse allowed without permission.

\section{Key Words}

Childhood Asthma

Allergen

Airway hyperreactivity

Epigenetics

Maternal Asthma 


\section{ABSTRACT}

Maternal asthma increases childhood asthma risk through multiple mechanisms including epigenetic regulation of asthma-associated genes. DNA methylation is one form of epigenetic regulation that is both inherited and modified by environmental exposures throughout life. In this study, we tested whether grandmaternal house dust mite (HDM) allergen exposure altered airway physiology and inflammation, as well as DNA methylation in both airway epithelium and airway sensory neurons of secondgeneration offspring. Grandmaternal allergen exposure induced a limited number of epigenetic changes in offspring at baseline that were not associated with increased airway reactivity or inflammation. In contrast, grandmaternal allergen exposure significantly altered offspring's response to HDM sensitization and challenge, inducing airway hyperreactivity to inhaled serotonin, increased airway inflammation, and potentiated DNA methylation. Gene sequences susceptible to methylation after allergen sensitization, and their corresponding biological processes and enriched pathways, were unique in offspring from HDM-exposed founders, indicating that grandmaternal allergen exposure established an epigenetic trajectory in offspring at birth that directed epigenetic and physiologic responses to subsequent allergen sensitization and challenge, contributing to inheritance of asthma risk. 


\section{INTRODUCTION}

Asthma is a chronic inflammatory airway disease that often begins in childhood and is characterized by airflow obstruction and airway hyperreactivity (Pijnenburg et al., 2021). Asthma prevalence has been increasing in recent decades and is more common within families (Paaso et al., 2014). While genetic predisposition is a major contributor to asthma risk (Paller et al., 2019, Young et al., 1991), it does not fully account for rising prevalence worldwide. Recent studies indicate that maternal asthma increases childhood asthma risk more than paternal asthma (Lim et al., 2010) and better maternal asthma control during pregnancy reduces a child's risk of asthma (Morten et al., 2018). Together, these studies suggest fetal exposure to maternal factors in utero may uniquely contribute to a child's asthma risk and serve as a modifiable exposure.

Epigenetic modification, namely DNA methylation of cytosine nucleotides located within $\mathrm{CpG}$ sites, is one potential mechanism by which environmental exposures can alter gene expression to increase asthma risk. DNA methylation contributes to type-2 $\left(T_{H} 2\right) T$ cell differentiation (Allan et al., 2012) and transcription of effector cytokines (Hosokawa et al., 2015), which correspond with increased asthma and atopy susceptibility (Barton et al., 2017, Seumois et al., 2014). Similarly, methylation changes at birth correlate with increased immunoglobulin E production throughout life (Han et al., 2021, Peng et al., 2018), possibly contributing to enhanced IgE-mediated allergen sensitization and atopy risk. The neonatal and early childhood epigenome is sensitive to maternal exposures that occur in utero, including maternal smoking (Joubert et al., 2016), stress (Trump et al., 2016), and asthma (Gunawardhana et al., 2014). Genome-wide and gene-specific differential methylation in early childhood predicts later development of asthma (Reese et al., 2019, den Dekker et al., 2019) and maternal asthma modifies gene-specific associations with asthma risk (DeVries et al., 2017), highlighting the impact of prenatal exposures and epigenetic changes on childhood asthma risk.

How epigenetic alternations identified at birth increase asthma risk later in life is not known. While differential genome-wide methylation is consistently found in children with asthma compared to children without asthma (Yang et al., 2017, Cardenas et al., 2019, 
Yang et al., 2015), differentially methylated genes are often not present at birth (Xu et al., 2018), suggesting methylation associated with asthma risk differs from that which manifest with disease onset. DNA methylation is a dynamic process that is both heritable and changes throughout life in response to environmental exposures. Allergen sensitization, a common feature in nearly two-thirds of asthmatics, correlates with broad methylation changes in atopic children (Peng et al., 2019). Similarly, exposure to allergens also leads to changes in DNA methylation in animals (Zhang et al., 2018, Peng et al., 2019, Kim et al., 2020a). Other environmental exposures associated with increased asthma risk, including air pollutants (Zhang et al., 2018) and viral infections (Spalluto et al., 2017, Pech et al., 2018), also modify DNA methylation, further confounding the relationship between epigenetic signatures at birth and signatures found in patients with established disease.

Epigenetic regulation is also tissue-specific. Most studies have utilized peripheral blood cells to compare epigenetic signatures between patients with and without asthma, however these cells may not reflect methylation changes in the lungs (Brugha et al., 2017, Lin et al., 2020). Few studies have yet to evaluate epigenetic signatures directly in the lungs in a cell-specific manner. Airway epithelial cells are of particular interest given that they line the interface between host and environment and initiate immunologic responses to inhaled allergens and other environmental exposures that contribute to both development of asthma and its exacerbations (Lambrecht and Hammad, 2012). Airway epithelium is also densely innervated by sensory neurons arising from vagal nodose-jugular ganglia, which detect inhaled stimuli and trigger reflex bronchoconstriction when activated (Drake et al., 2018, Lebold et al., 2019). Identifying epigenetic signatures in these key cells at the lung-environment interface and correlating epigenetic changes with disease features such as airway hyperreactivity and inflammation will help elucidate connections between epigenetic regulation and disease pathogenesis.

In the current study, we hypothesized that grandmaternal asthma creates an intergenerational, tissue-specific epigenetic signature that is established at birth and 
informs epigenetic trajectories after allergen sensitization. We tested our hypothesis by comparing CpG methylation in airway epithelial cells and vagal sensory neurons before and after HDM allergen sensitization, as well as airway physiology and inflammation after HDM sensitization and challenge, in second generation offspring descended from allergen-exposed and vehicle-exposed founding grandmothers.

\section{RESULTS}

\section{Grandmaternal allergen exposure potentiates airway hyperreactivity and inflammation in second-generation offspring}

Airway physiology and inflammation were assessed after HDM sensitization and challenge in second-generation offspring (F2) from HDM-exposed and vehicle-exposed grandmaternal founders (F0) (Figure 1). Airway reactivity to inhaled serotonin was similar between vehicle-challenged F2 offspring from F0 HDM-exposed founders (FOHDM•F2Veh) and vehicle-challenged F2 offspring from vehicle-exposed F0 founders (F0Veh•F2Veh) (Figure 2A), indicating that grandmaternal allergen exposure did not affect offspring's airway reactivity at baseline. HDM sensitization and challenge of F2 mice caused airway hyperreactivity in descendants from both HDM- and vehicleexposed F0 lineages. However, F2 airway hyperreactivity was significantly potentiated in offspring from the grandmaternal HDM-exposed lineage (FOHDM•F2HDM) compared to offspring of the vehicle-exposed F0 lineage (F0Veh•F2HDM).

Similarly, airway inflammation after HDM sensitization and challenge was also augmented in the F2 generation after grandmaternal HDM exposure. Specifically, total bronchoalveolar lavage leukocytes and eosinophils were significantly increased in HDM-challenged F2 mice from HDM-exposed F0 founders (FOHDM•F2HDM) compared to HDM-challenged F2 mice from vehicle-exposed F0 founders (F0Veh•F2HDM) (Figure 2B-F). Macrophages, neutrophils, and lymphocytes were increased as well, but did not reach statistical significance. Grandmaternal allergen exposure did not affect second generation offspring's airway inflammation at baseline as no differences were observed between vehicle-challenged F2 mice from the F0 HDM lineage 
(F0HDM•F2Veh) compared to vehicle-challenged F2 mice from the vehicle-exposed F0 lineage (FOVeh•F2Veh).

\section{Grandmaternal allergen exposure alters DNA methylation in allergen-naïve second generation offspring}

To test whether grandmaternal allergen exposure affects offspring DNA methylation at baseline before allergen sensitization, F2 mice from HDM-exposed F0 founders (FOHDM•F2Base) were compared to F2 mice from vehicle-exposed founders (F0Veh•F2Base). In total, 290 differentially methylated regions (DMRs) were detected in airway epithelium of FOHDM•F2Base compared to FOVeh•F2Base, which overlapped 297 unique genes. Of these DMRs, 177 (61\%) were hypermethylated, while 113 (39\%) were hypomethylated. Most DMRs spanned intra- and intergenic DNA segments, while 18\% mapped to promoters (Figure 3). Likewise, 1,390 differentially methylated cytosines (DMCs) were detected in airway epithelium of F0HDM•F2Base compared to F0Veh•F2Base, of which 804 (58\%) were hypermethylated and 586 (42\%) were hypomethylated. Again, most DMCs mapped to intra- and intergenic sequences, with $18 \%$ spanning promoters (Figure S1).

Gene ontology (GO) terms were used to assess for pathways and biological processes enriched in these DMRs and DMCs. For DMCs, 74 biologic processes were significantly enriched and subsequently grouped into functionally related gene clusters, including most prominently, calcium homeostasis, bone morphogenetic protein response, and cell and organ development (Figure 4A). No biological processes were associated with DMRs, nor were any pathways enriched within DMRs or DMCs (Table 1).

\section{Allergen sensitization provokes a predominantly hypomethylated response in airway epithelium of second generation offspring from control founders}

To test how allergen sensitization alone affected F2 methylation, DMRs and DMCs were assessed in airway epithelium of HDM-sensitized F2 mice (F0Veh•F2Sens) compared to non-sensitized F2 mice (F0Veh•F2Base), both from the vehicle-exposed F0 lineage. In total, 261 DMRs were identified that overlapped 277 unique genes. One hundred and 
sixty one (61.7\%) were hypomethylated and 100 (38.3\%) were hypermethylated. Most DMRs spanned intra- and intergenic sequences, with $20.3 \%$ mapping to promoters (Figure 3). We identified 1,362 DMCs, of which 754 (55.4\%) were hypomethylated and 608 (44.6\%) were hypermethylated. Similar to DMRs, most DMCs identified covered inter- and intragenic sequences, with 20.3\% mapping to promoters (Figure S1).

Pathways associated with F0Veh•F2Sens DMRs included beta-1 and beta-2 adrenergic signaling, oxytocin receptor signaling, and $5 \mathrm{HT} 2$ serotonin receptor signaling pathways (Table 1). Additional pathways associated with DMCs included integrin signaling and thyrotropin-releasing hormone signaling pathways. Gene ontology analysis indicated that DMRs and DMCs were enriched for several biologic processes as well, including most notably, cell growth and migration, actin organization, and neuron development (Figure 4B).

\section{Grandmaternal allergen exposure potentiates DNA methylation and alters enriched pathways in allergen sensitized second generation offspring}

To test whether grandmaternal allergen exposure alters F2 methylation after HDM sensitization, HDM sensitized F2 offspring (F0HDM•F2Sens) were compared to nonsensitized F2 offspring (FOHDM•F2Base), both from HDM-exposed F0 founders. A greater number of DMRs and DMCs were identified after allergen sensitization in F2 offspring from HDM-exposed founders compared to F2 offspring from vehicle-exposed founders. A total of 1,234 DMRs (Figure 3) and 3,756 DMCs (Figure S1) were identified in airway epithelium of FOHDM•F2Sens offspring, corresponding with 1,205 genes. Allergen sensitization also caused hypermethylation of most DMRs and DMCs in F0HDM•F2Sens offspring as compared to hypomethylation in F0Veh•F2Sens offspring.

Of the 1,234 DMRs, 809 (65.6\%) were hypermethylated, while 425 (34.4\%) were hypomethylated. Most DMRs spanned introns, while 236 (19.1\%) mapped to promoters (Figure 3) in FOHDM•F2Sens offspring. Of DMCs identified in this group, 2,261 (60.2\%) were hypermethylated and 1,495 (39.8\%) were hypomethylated. Similar to DMRs, most DMCs spanned introns, while 642 (17.1\%) mapped to promoters (Figure S1). 
Pathway analysis of differentially methylated regions identified in FOHDM•F2Sens offspring included endothelin, platelet derived growth factor, Wnt, and gonadotropinreleasing hormone signaling pathways. Pathway analysis of DMCs also included enrichment for GABA-B receptor II, histamine $\mathrm{H} 1$ receptor, oxytocin receptor, nicotinic receptor, 5HT2 serotonin receptor, and cholecystokinin receptor signaling (Table 1).

Gene ontology analysis of DMCs demonstrated that grandmaternal allergen exposure changed enriched biological processes after allergen sensitization in F2 offspring. A total of 418 biological processes were enriched after allergen sensitization in FOHDM $\cdot F 2$ Sens offspring compared with 97 after allergen sensitization in FOVeh॰F2Sens (Figure 4C). After grouping functionally related GO terms, the most notably represented biological processes included axonogenesis, cell proliferation, innate immunity, cytoskeleton regulation and kinase activity regulation.

\section{Epigenetic changes in airway epithelial cells after allergen sensitization are uniquely regulated by grandmaternal allergen exposure}

To test whether maternal HDM exposure affects DNA methylation after allergen sensitization in offspring, DMR-associated genes were compared in allergen sensitized F2 offspring from HDM-exposed and vehicle-exposed F0 founders (FOHDM•F2Sens vs. F0Base•F2Sens). In total, only 29 genes were in common between the 1,205 genes associated with DMRs in FOHDM•F2Sens mice and 277 genes associated with DMRs in F0Veh•F2Sens mice (Figure 5A), indicating that maternal allergen exposure provokes a fundamentally unique methylation response after allergen sensitization in F2 mice.

Furthermore, only 11 of 29 genes changed in the same direction (i.e. hypo- or hypermethylation), while the remaining 18 were differentially regulated between groups (Figure 5B).

\section{Multiple transcription factor binding sites are enriched in allergen-sensitized offspring from allergen-exposed founders}

Since transcription factor binding sites regulate gene expression, enrichment of specific transcription factor binding sites within DMRs was analyzed in all groups. Several 
transcription factor binding sites were enriched in epithelial DMRs of allergen-sensitized offspring from allergen-exposed founders (F0HDM•F2Sens vs. FOHDM•F2Base) including several factors related to AP-1 factor family and p53 factor family (Table 2). In contrast, the few binding sites present in DMRs of allergen-sensitized F2 offspring from vehicle-exposed founders (F0Veh•F2Sens vs F0Veh•F2Base) and in non-sensitized F2 offspring from grandmaternal allergen exposed founders (FOHDM•F2Base vs FoVeh•F2Base) primarily related to the ETS family of factors.

\section{Grandmaternal allergen exposure influences epigenetic signatures of vagal ganglion sensory neurons}

To test whether grandmaternal HDM exposure affected DNA methylation in vagal ganglia sensory neurons, F2 offspring from allergen-exposed F0 founders (FOHDM•F2Base) were compared to F2 mice from vehicle-exposed founders (F0Veh•F2Base). A total of 211 DMRs and 901 DMCs were detected in F0HDM•F2Base mice. Similar to airway epithelium, a majority of DMRs and DMCs in FOHDM•F2Base mice were hypermethylated, including 127 (60.2\%) DMRs and 536 (59.5\%) DMCs (Figure 6 and Figure S2). No pathways or biological processes were associated with differentially methylated regions or cytosines (DMRs or DMCs) in this comparison (Table 3).

The 211 DMRs in vagal ganglia from FOHDM•F2Base mice corresponded to 222 unique genes, which were then compared with 297 genes detected in airway epithelium of the same mice. Only 14 genes were in common between vagal ganglia and airway epithelium, demonstrating that most epigenetic changes caused by grandmaternal HDM exposure occurred in a tissue-specific context.

Next, to determine the effects of allergen sensitization alone on vagal ganglia epigenetic signatures, HDM-sensitized F2 mice were compared to non-sensitized F2 mice from vehicle-exposed grandmothers (F0Veh•F2Sens vs. F0Veh•F2Base). A total of 346 DMRs and 1,467 DMCs were detected and were evenly balanced between hyper- and hypomethylation (Figure 6 and Figure S2), with 174 (50.3\%) DMRs and 795 (54.2\%) of 
DMCs being hypermethylated. Pathways associated with allergen sensitization in vagal ganglia of FOVeh•F2Sens included metabotropic glutamate receptor group III, platelet derived growth factor and cholecystokinin receptor signaling (Table 3). Gene ontology analysis indicated that several biologic processes were enriched, most notably axonogenesis, cell projection, cell adhesion and synapse organization (Figure S3).

Effects of grandmaternal HDM exposure on F2 methylation after HDM sensitization were determined by comparing HDM-sensitized F2 offspring from HDM-exposed founders (FOHDM•F2Sens) to non-sensitized F2 mice from HDM-exposed F0 founders (FOHDM•F2Base). Four hundred and thirteen DMRs and 1,787 DMCs were identified (Figure 6 and Figure S2), of which 242 (58.6\%) DMRs and 892 (49.9\%) DMCs were hypermethylated. No pathways were associated with DMRs, whereas, similar to findings in airway epithelial cells, gonadotropin-releasing hormone and Wnt signaling pathways were associated with DMCs (Table 3). Enriched biological processes included axonogenesis and transmembrane cation transport (Figure S3).

\section{Epigenetic changes in vagal ganglia after allergen sensitization are altered by grandmaternal allergen exposure}

DMR-associated genes were compared between allergen-sensitized F2 offspring from HDM-exposed and vehicle-exposed F0 founders (FOHDM•F2Sens vs. FOVeh•F2Sens). In total, 21 genes were shared between 222 genes associated with DMRs in F0Veh•F2Sens mice and 413 genes associated with DMRs in FOHDM•F2Sens mice (Figure 7A). Of the 21 genes in common, only 7 had a matching pattern of hypo- or hypermethylation (Figure 7B). 


\section{DISCUSSION}

In recent years, the epigenome has drawn intense interest as one potential explanation for the epidemic rise in asthma (DeVries and Vercelli, 2016). DNA methylation represents one epigenetic mechanism by which rapid phenotypic adaptations after environmental exposures can be transmitted from one generation to the next. Exposures to maternal factors during fetal lung development may be particularly impactful to asthma risk. However, linking specific maternal factors to epigenetic changes and developmental outcomes in humans has been challenging due to human longevity and confounding from a myriad of pre- and post-natal exposures. Maternal smoking has been most strongly linked with epigenetic changes associated with altered lung development and asthma risk (Hylkema and Blacquiere, 2009, Gilliland et al., 2000, Patil et al., 2013, Li et al., 2005). Maternal diet (Chatzi et al., 2008), stress (Gheorghe et al., 2010) and diesel exhaust exposure (Liu et al., 2008) have also been associated with alterations in the epigenome, and specific CpG methylation sites have been associated with atopy and asthma in children (Patil et al., 2013, Everson et al., 2015). Epigenetic changes regulate immune cell development including Th1, Th2, and T-regulatory cell differentiation (White et al., 2002, Fields et al., 2002, Baron et al., 2007) and differences in immune function can be detected at birth (Rinas et al., 1993, Ohshima et al., 2002), suggesting prenatal programming influences a child's response to environment exposures from the earliest moments of life.

In animal models, particularly in mice, several factors are linked to transgenerational epigenetic regulation. For example, maternal diesel exhaust exposure altered dendritic cell DNA methylation that persisted across three generations and was associated with increased airway inflammatory responses to ovalbumin antigen in offspring (Gregory et al., 2017). A second study found that maternal HDM exposure altered methylation patterns in whole lung homogenates that were detectable in three successive generations and were associated with enhanced airway inflammation and airway responsiveness after HDM challenge (Pulczinski et al., 2021). Unlike this latter study, our analysis focused specifically on airway epithelium and vagal sensory neurons since methylation changes are highly cell specific (as shown by the different results we 
obtained in these two tissues). The central role of airway epithelium in the initiation of allergic asthma as both the site of contact for inhaled particles and as a key source of proinflammatory cytokines (Roan et al., 2019), and the important role of airway sensory neurons in regulating reflex bronchoconstriction and hyperreactivity make these two tissues of special interest.

Using the mouse model, we show that grandmaternal allergen exposure potentiates allergic airway inflammation and airway hyperreactivity in second-generation offspring. These effects were associated with significant alterations in offspring's epigenetic signature at baseline and reprogramming of their epigenetic response to allergen sensitization later in life, in a tissue-specific context.

In our experiments, DMRs and DMCs associated with allergen sensitization alone (i.e. allergen-sensitized F2 mice from the control lineage) mapped to voltage-gated L-type calcium channels involved in multiple $G$ protein coupled receptor signaling pathways (i.e. beta adrenergic receptors, 5-HT2 receptors, oxytocin receptors and thyrotropinreleasing hormone receptors), and to the integrin signaling pathway, both of which contribute to normal airway function. L-type calcium channels on epithelium regulate mucin secretion (Khakzad et al., 2012) and are involved in branching morphogenesis during development (Brennan et al., 2013), whereas airway integrins are essential for cellular adhesion and maintenance of epithelial barrier function (Wright et al., 2014). Loss of epithelial barrier integrity has been implicated in asthma pathogenesis and specific integrins that were differentially methylated in our study, such as integrin B4, are down-regulated in humans with asthma (Wu et al., 2020, Liu et al., 2010). Mice with integrin B4 deficiency exhibit accelerated epithelial cell senescence (Yuan et al., 2019) and have an exaggerated inflammatory response to allergen (Liu et al., 2018). Inhibition of other integrin signaling mediators identified in our analysis, such as PiK3, also result in potentiated inflammatory responses and airway hyperreactivity in mice (Lee et al., 2006), suggesting that dysregulation at multiple levels of integrin signaling may exacerbate responses to allergens. 
Importantly, our data also show that grandmaternal allergen exposure fundamentally alters future generations epigenetic response to allergen sensitization. In allergensensitized offspring from allergen-exposed founders, DMRs and DMCs mapped to several signaling pathways that regulate lung development and inflammation, including WNT signaling, platelet derived growth factor signaling, gonadotropin-releasing hormone receptor pathway, and endothelin receptor signaling. Differentially methylated WNT proteins in our model included LRP5 and Axin2, which regulate airway branching and alveolar morphogenesis in developing fetal lungs (Mammoto et al., 2012, Frank et al., 2016, Zhang et al., 2012). Other differentially methylated genes coding WNT proteins, such as Nfatc2 (Jakobi et al., 2020, Hinds et al., 2013) and PCDH1 (Koppelman et al., 2009) have been identified as novel susceptibility loci for development of allergy and bronchial hyperreactivity in humans, respectively. PCDH1 polymorphisms were associated with development of asthma in children (Mortensen et al., 2014, Faura Tellez et al., 2015) and PCDH1 function was critical to epithelial barrier function in vitro (Kozu et al., 2015). Expression of WNT3, WNT5a, WNT10 and their receptor, Fzd-5, positively correlated with type 2 high asthma in adults while expression of WNT5b was negatively correlated with a type 2 signature (Choy et al., 2011). Tle3 regulated T cell development (Xing et al., 2018) and loss of WNT10b enhanced airway inflammation in a murine model (Trischler et al., 2016). Functionally, WNT signaling is critical to epithelial-mesenchymal differentiation during development (Sharma et al., 2010, Dean et al., 2005) and at times of lung injury (Konigshoff and Eickelberg, 2010), where their ability to broadly influence transcriptional events regulates airway inflammation and epithelial repair.

Other over-represented pathways in allergen-sensitized offspring of allergen-exposed founders included PDGFR signaling and endothelin receptor signaling. PDGF family proteins are involved in cell proliferation and migration during embryogenesis and contribute to airway remodeling by inducing epithelial metaplasia and airway smooth muscle migration in later life (Cohen et al., 2009). PDGF mediators MEK1 and Pi3k contributed to airway epithelial cell differentiation during development (Boucherat et al., 2014) and mediated epithelial cytokine production after HDM exposure in adult mice 
(Kim et al., 2020b). Consequently, blocking PI3K reduced aspergillus-induced allergic airway inflammation in mice (Jeong et al., 2018). Similarly, endothelin pathway mediators played an important role initiating eosinophilic inflammation after allergen (Finsnes et al., 1998). In rats, endothelin levels rapidly increased in bronchoalveolar lavage fluid and in airway epithelium after allergen exposure and airway inflammation was blocked by endothelin receptor antagonists (Finsnes et al., 1997). The endothelin signaling protein ITPR2 is important for cellular adhesion as well as T and B cell activation (Patterson et al., 2004) and ITPR2 polymorphisms are associated with asthma in humans (Wilker et al., 2009). Endothelin also has the ability to directly induce human airway smooth muscle contraction (Advenier et al., 1990). Thus, differential methylation in our study has identified pathways involving airway immune responses, lung development, and airway contractility.

Gene ontology analysis demonstrated greater enrichment of biological processes in allergen-sensitized offspring from the allergen-exposed lineage. Foremost among these processes were cell proliferation, regulation of kinase activity, innate immunity, axonogenesis and cytoskeleton regulation, all of which were parts of a larger theme of cellular migration and organ morphogenesis. In contrast, allergen sensitization alone (i.e. allergen-sensitized offspring from control founders), and effects of maternal allergen exposure alone (i.e. control offspring from allergen-exposed F0 mice), affected only a small fraction of developmental processes.

Several transcription factor binding sites were enriched in epithelial DMRs of allergensensitized offspring from allergen-exposed founders, including members of the AP-1 and p53 factor families. Transcription factor binding sites, which are typically located near promoters, increase or decrease gene transcription. It is therefore possible that these DMRs act as regulatory sites and their differential methylation might impact accessibility to binding from transcription factors (Tulchinsky et al., 1996). AP-1 consists of Fos (c-Fos, FosB, FosL1, FosL2) and Jun (c-Jun, JunB, JunD) proteins, which form dimers that regulate transcription of inflammatory genes relevant to asthma, such as cFos and interleukin (IL)-5, and Fra2 and IL-13 (Liu et al., 2004, Gungl et al., 2018, 
Ferreira et al., 2020). AP-1 binding also reduces glucocorticoid receptor binding site availability by altering chromatin structure (Adcock et al., 1995, Jacques et al., 2010), suggesting AP-1 has a role in development of corticosteroid-resistant disease.

Accordingly, in asthma and particularly in corticosteroid-resistant asthma, expression of AP-1 dimers (e.g. c-Fos) is increased (Sousa et al., 1999, Lane et al., 1998). AP-1 can also be activated by inflammatory cytokines TNF-alpha and IL-1beta, suggesting transcription factor activity is amplified by its own downstream products.

The p53 transcription factor family includes structurally similar factors p53, p63, and p73. While more commonly known for their role as tumor suppressors, p53 and p63 are involved in epithelial cell senescence and epithelial wound repair, respectively (Warner et al., 2013, Moheimani et al., 2015). Both of these processes are implicated in asthma pathogenesis. p73 also has a role in mucociliary development. Thus, p53-associated factors have several potential implications for lung development and disease pathogenesis.

Our analysis included an evaluation of methylation in airway sensory neurons since 1) airway nerves control bronchoconstriction (Drake et al., 2021) 2) sensory nerve remodeling correlated with worse lung function and increased irritant sensitivity in humans with eosinophilic asthma (Drake et al., 2018) and 3) maternal type-2 inflammation in mice increased airway sensory nerve density and nerve-mediated airway hyperreactivity after allergen exposure in first generation offspring (Lebold et al., 2019). Grandmaternal allergen exposure significantly altered methylation in sensory nerves at baseline and after allergen sensitization. In total, only 21 genes corresponding to DMRs were shared between allergen-sensitized offspring from allergen-exposed versus control lineages, lending further evidence that grandmaternal allergen exposure results in a substantial tissue specific reprograming of epigenetic responses to allergen. While individual genes associated with DMRs varied markedly between vagal ganglia and airway epithelium in F2 offspring from allergen-exposed founders, enriched pathways were similar, including PDGF signaling, gonadotropin releasing hormone receptor signaling, and WNT signaling pathways. Additional involvement of 
cholecystokinin receptor signaling in vagal ganglion at baseline occurred as the result of grandmaternal allergen exposure. Cholecystokinin is a typically associated with sensory nerve activation in the gut, with less known about its role in sensory neurons in airways. Cholecystokinin expression in neuroendocrine bodies has been detected in lower airways in sheep (Balaguer et al., 1992) and airway sensory nerves increase cholecystokinin receptor expression after lung injury (Kaelberer et al., 2020), possibly resulting in increased bronchoconstriction in humans (Stretton and Barnes, 1989).

In summary, our study indicates that grandmaternal allergen exposure increases airway reactivity and inflammation in offspring after allergen sensitization and challenge, in association with reprogramming of epigenetic responses to allergen sensitization. We showed that epigenetic trajectories are established before birth in response to prenatal exposures, which direct subsequent epigenetic responses to allergen sensitization and contribute to transgenerational inheritance of asthma risk. 


\section{METHODS}

\section{Mice}

Male and female C57BI/6J mice (Jackson Laboratories, Bar Harbor, ME) were 8-14 weeks old at time of experimentation. Mice were housed in filtered air rooms with ad libitum access to food and water on a 12-h light/dark cycle and were treated in accordance with standards established by the United States Animal Welfare Act set forth by the National Institutes of Health guidelines. The Institutional Animal Care and Use Committee at Oregon Health \& Science University approved all experimental protocols.

\section{Grandmaternal (FO) Allergen Exposure}

Nulliparous female mice were exposed to $25 \mu \mathrm{g}$ house dust mite (HDM, dissolved in 25 $\mu \mathrm{L}$ PBS, Greer Laboratories, $n=10$ mothers) or vehicle (PBS, $n=10$ mothers) for 7-8 total weeks. For the first 4 weeks, mice were sedated with $5 \%$ isoflurane and intranasally exposed to HDM or vehicle once daily on 5 consecutive days per week (Figure 1). At the end of week 4 , females were paired with untreated males for breeding. From week 5 until delivery, pregnant females were manually restrained without isoflurane sedation, since pilot studies showed daily sedation caused fetal demise, and exposed intranasally with $25 \mu \mathrm{g} \mathrm{HDM}$ or vehicle, 5 days per week through gestation until birth. Maternal treatments ceased at time of delivery.

\section{First Generation Offspring (F1) Breeding Scheme}

First generation offspring (F1) were randomly mated with offspring born to different F0 mothers from the same treatment group (HDM or Veh) at 8 weeks of age. Thus, each mated pair represented an $\mathrm{F} 1$ male offspring and an $\mathrm{F} 1$ female offspring from different F0 mothers, resulting in $n=5$ mating pairs. F1 mice were not sensitized with HDM and received no other treatments. 
F2 offspring mice 8-12 weeks of age were anesthetized with $5 \%$ isoflurane and sensitized with $50 \mu \mathrm{g}$ HDM i.n. or vehicle on days 0 and 1. On day 14, one cohort of mice were utilized for methylation analysis while a second cohort underwent allergen challenge with $25 \mu \mathrm{g}$ HDM or vehicle i.n. on days 14-17. Airway physiology and inflammation were measured on day 18.

\section{Assessments of Airway Physiology and Inflammation}

F2 mice airway physiology was measured as previously described (Lebold et al., 2019). Briefly, mice that were randomly assigned for physiologic studies were sedated with ketamine (100 mg/kg i.p.) and xylazine (10 mg/kg i.p.), paralyzed with succinylcholine (10 mg/kg i.p.), tracheotomized, and mechanically ventilated via a 21 -gauge catheter. A constant volume ventilator delivered $200 \mu \mathrm{L}$ tidal volumes at 125 breaths/min with an inspired oxygen content of $95 \%$ oxygen $/ 5 \% \mathrm{CO} 2$ and $2 \mathrm{~cm} \mathrm{H} \mathrm{H}_{2} \mathrm{O}$ of positive endexpiratory pressure. Flow and pressure were continuously monitored (AD Instruments) and aerosolized serotonin (10-1000 mM; AeroNeb, Torrington, CT) was delivered at 2 minute intervals. Airway resistance, calculated as the difference between peak inspiratory pressure and plateau pressure during an end inspiratory pause, divided by airflow (Resistance $=$ Ppeak-Pplateau / flow) was measured 60 seconds after each dose of serotonin and expressed as fold change over resistance to aerosolized PBS.

Bronchoalveolar lavage was performed by instilling $0.5 \mathrm{ml}$ sterile PBS three times into the lungs via the tracheal cannula. Total cells were determined with a hemacytometer and cell differentials measured using Wright staining.

\section{DNA Isolation, Extraction and Purification}

Mice that were randomly assigned for DNA isolation were injected with a lethal dose of pentobarbital (150 mg/kg i.p.) and perfused with sterile PBS. Tracheas and primary bronchi were excised and incubated in 0.5\% protease solution in RPMI medium containing penicillin-streptomycin-amphotericin $\mathrm{B}$ at $4^{\circ} \mathrm{C}$ overnight, followed by fresh protease solution at $37^{\circ} \mathrm{C}$ for 30 minutes. Airway epithelium was then isolated by instilling sterile PBS through the tracheal lumen. Isolated cells were counted using a 
hemocytometer and $>95 \%$ cell viability was confirmed with Trypan Blue. Concurrently, mouse vagal ganglia were removed and placed in sterile cell lysis buffer (Qiagen Puregene, Hilden Germany) with $0.5 \%$ SDS and $100 \mathrm{ug} / \mathrm{ml}$ Proteinase $\mathrm{K}$ at $55^{\circ} \mathrm{C}$ overnight. Both epithelium and vagal sensory neurons were stored in sterile cell lysis buffer prior to DNA extraction.

DNA were extracted from airway epithelial cells and vagal sensory neurons using Gentra Puregene Tissue (Qiagen) and purified using gDNA Clean and Concentrator 10 columns (Zymo Research, Irvine, CA) by the Gene Profiling Shared Research Core at OHSU. DNA concentration and purity were assessed by UV absorption (Nanodrop One, ThermoFisher, Waltham, MA), size analysis was performed using the gDNA Tape method (2200 TapeStation, Agilent, Santa Clara, CA), and quantification was performed using PicoGreen fluorescence assay (Sigma, Burlington, MA).

Reduced-representation bisulfite sequencing (RBSS) library generation RRBS libraries were generated as previously described (Carbone et al., 2019). Briefly, DNA (100-150 ng) from epithelium or sensory neurons underwent digestion for 10 hours at $37^{\circ} \mathrm{C}$ with $\mathrm{Msp} /$ restriction enzyme (New England Biolabs, Ipswich, MA), followed by purification with AMPure XP (Beckman Coulter, Indianapolis, IN). Libraries were generated with a NEXTflex Bisulfite-Seq Kit (Bioo Scientific Corporation, Austin, TX) paired with the NEBNext Methylated Adaptor (New England Biolabs). Bisulfite conversion was performed with a EZ DNA Methylation-Gold Kit (Zymo Research) followed by PCR amplification with NEBNext Multiplex Oligos (New England Biolabs). Libraries were quantified with the Qubit High Sensitivity dsDNA Assay (Life Technologies, Eugene, OR), and multiplexed for sequencing on the Illumina NextSeq 500 with the high-output, 75-bp cycle protocol.

\section{Differential methylation analysis}

RRBS reads were analyzed for quality with FastQC (v0.11.5), followed by trimming with TrimGalore (v0.5.0) with the "-rrbs" parameter specified. Trimmed reads were aligned to the Ensembl mouse reference genome (GRCm38) with Bismark (v0.19.0) (Krueger 
and Andrews, 2011) using default parameters. Alignment rates were approximately $75 \%$, consistent with typical bisulfite-converted sample alignment. For differentially methylated cytosines (DMC) analysis, only CpGs with at least 10X coverage and less than the $99.9^{\text {th }}$ percentile of the highest coverage CpGs in at least 4 replicates per group in a given tissue were considered. In total, 514,227 CpGs were used for epithelial DMC analysis and 541,043 CpGs were used in vagal sensory neuron DMC analysis. DMC were identified using a logistic regression model that utilized a Chi-square test, taking biological replicates into account and considering sex as a covariate in the model to calculate P-values. P-values were corrected to q-values using the SLIM method. A q value $<0.1$ and an absolute methylation percent difference $>10 \%$ was considered significant. Differentially methylated region (DMR) analysis was performed by comparing non-overlapping 1000bp segments between experimental and reference genomes using logistic regression, as previously described (Akalin et al., 2012). Genes associated with DMCs and DMRs were annotated using Ensembl annotation GRCm38.92 and a custom script that utilized BEDTools (Quinlan and Hall, 2010) and the genomation $\mathrm{R}$ library (Akalin et al., 2015). For intergenic DMRs, the closest gene and the distance between the DMC/DMR and Transcription Start Site (TSS) was also annotated.

\section{Gene Ontology and Pathway Analysis}

Gene ontology (release date 20210101) and pathway analysis of significant DMCs and DMRs were performed with Panther (release date 20200728). Hypo- and hypermethylated regions were jointly analyzed using overrepresentation with Fischer's exact test and FDR correction (FDR<0.05). Over and underrepresented biological process GO terms with > 5 and $<1000$ genes were visualized using Cytoscape Enrichment Map and shared gene clusters with functionally related GO terms were labeled.

\section{Transcription Factor Binding Site Analysis}

Enrichment of transcription factor binding sites within significant DMRs was performed using HOMER Motif Enrichment (Heinz et al., 2010), specifically the 
"findMotifsGenome" script. The percentage of target sequences with a given motif were compared to the percentage of background sequences with a given motif. Only sequences with a q-value $<0.05$ were considered significant.

\section{Statistics}

Airway physiology data were analyzed with a repeated-measures two-way ANOVA with a Tukey's post-test using Prism (Graphpad). Physiologic data that were greater than 2 standard deviations above or below their gender and group mean were considered outliers and excluded from analysis. Final $\mathrm{N}$ for each group were as follows:

F0Veh•F2Veh n=13, FOVeh•F2HDM n=20, F0HDM•F2Veh n=13, FOHDM•F2HDM $\mathrm{n}=18$. Bronchoalveolar lavage cell count data were analyzed with a two-way ANOVA and Tukey's post-test. Hypo- and hypermethylated regions were jointly analyzed using overrepresentation with Fischer's exact test and FDR correction (FDR $<0.05)$. Genomics data was assessed using $R$ as described above. 


\section{FIGURE LEGENDS}

Figure 1. Breeding scheme and house dust mite sensitization protocol. Female F0 mice (grey mice, "F") were exposed to intranasal house dust mite (HDM) or vehicle (Veh) for five consecutive days followed by two days of rest for 4 weeks, mated, and then exposed to HDM or vehicle 5 days per week through gestation until birth. Male F0 mice (white mouse, "M") received no treatment. F1 male and female offspring were randomized into breeding pairs and received no treatments. Male and female F2 offspring were either sensitized to HDM or treated with Veh on days 0 and 1 and then challenged with HDM (FOVeh•F1HDM and F0 HDM•F1HDM) or vehicle (FOVeh•F1Veh and $\mathrm{FOHDM} \cdot \mathrm{F} 1 \mathrm{Veh}$ ) on days 14-17. Airway physiology and bronchoalveolar lavage leukocytes were measured on protocol day 18. A subset of F2 mice were euthanized before allergen sensitization (FOVeh•F1Base and FOHDM•F1Base) and after HDM sensitization (sensitized day 0 and 1 , euthanized day 14; F0Veh•F1Sens and $\mathrm{FOHDM} \cdot \mathrm{F} 1$ Sens) for methylation experiments.

Figure 2. Allergen-induced airway hyperreactivity and inflammation is potentiated in second-generation offspring of HDM-exposed founders.

Airway resistance was measured after escalating concentrations of aerosolized serotonin in ventilated F2 mice. Airway hyperreactivity occurred after HDM-challenge in F2 mice (FOVeh•F2HDM and FOHDM•F2HDM) compared to vehicle-challenged F2 mice (FOVeh•F2Veh and FOHDM•F2Veh). HDM-induced airway hyperreactivity was potentiated in F2 mice from HDM-exposed F0 mice (FOHDM•F2HDM) compared to F2 mice from vehicle-exposed F0 mice (F0Veh॰F2HDM). Vehicle-challenged F2 offspring from both lineages had similar airway reactivity to inhaled serotonin. $N=13-20 /$ group; $p<0.05$ based on two-way ANOVA with repeated measures. (B-F) Total airway inflammatory cells and differential cell counts were measured in bronchoalveolar lavage. Grandmaternal HDM exposure potentiated HDM-challenge induced airway inflammation in F2 offspring, including total leukocytes (B) and eosinophils (C). Neutrophils (D), macrophages $(E)$, and lymphocytes $(F)$ were also increased, but did not reach significance. 
Figure 3. Grandmaternal allergen exposure alters airway epithelial DNA methylation at baseline and after allergen sensitization in second-generation offspring. Whole genome methylation was assessed in airway epithelium of secondgeneration mice (F2) before and after allergen sensitization. Grandmaternal HDM exposure alone resulted in 290 differentially methylated regions (F0 HDM•F2 Base versus F0 Veh॰F2 Base) with a predominantly hypermethylated response. F2 HDM sensitization alone resulted in 261 differentially methylated regions with a predominantly hypomethylated response (FOVeh॰F2Sens versus F0 Veh•F2 Base). In contrast, HDMsensitized F2 mice from HDM-exposed F0 founders had 1,234 total differentially methylated regions with a predominantly hypermethylated response (F0 HDM•F2 Sens versus F0 HDM•F2 Base).

Figure 4. Gene ontology analysis of DMCs in airway epithelium of secondgeneration offspring.

Gene ontology analysis of DMCs in airway epithelium of F2 mice identified enriched biological processes (individual small circles), which were then grouped based on functional annotation using Cytoscape Enrichment Map (larger, labeled, black circles). Each small circle represents an individual biological process and size is proportional to number of involved genes, while connecting edges represent shared genes between individual biological processes. (A) Gene ontology analysis showing enriched biological processes due to grandmaternal $\mathrm{HDM}$ exposure in $\mathrm{F} 2$ offspring at baseline (F0 $\mathrm{HDM} \cdot \mathrm{F} 2$ Base versus F0 VEH•F2 Base). (B) Gene ontology analysis showing effects of HDM sensitization alone on enriched biological processes in $\mathrm{F} 2$ offspring from vehicleexposed F0 mice (F0 Veh॰F2 Sens vs F0 VEH•F2 Base). (C) Gene ontology analysis showing potentiating effects of $\mathrm{FO}$ grandmaternal HDM exposure on enriched biological processes after HDM sensitization in F2 mice (F0 HDM•F2 Sens vs F0 HDM•F2 Base).

Figure 5. Unique genes are differentially methylated in airway epithelium after allergen sensitization in offspring from HDM-exposed founders. 
DMR-associated genes in HDM-sensitized F2 mice from HDM-exposed founders were compared against DMR-associated genes in HDM-sensitized F2 mice from vehicleexposed founders to assess for common genes. (A) Twenty-nine genes were shared between F0 Veh•F2 Sens and F0 HDM•F2 Sens groups, out of 277 total genes in F0 Veh॰F2 Sens mice and 1,205 total genes in F0 HDM•F2 Sens mice. (B) Of these 29 genes, 11 were similarly hyper- or hypomethylated between lineages, while 18 were differentially methylated.

Figure 6. Grandmaternal allergen exposure alters vagal ganglion DNA methylation at baseline and after allergen sensitization in second-generation offspring. Grandmaternal HDM exposure alone resulted in 211 DMRs (F0 HDM•F2 Base versus F0 Veh•F2 Base) in vagal ganglia. F2 HDM sensitization alone resulted in 346 DMRs (F0Veh•F2Sens versus F0 Veh•F2 Base). In contrast, HDM sensitization of F2 mice from HDM-exposed founders resulted in 413 DMRs (F0 HDM•F2 Sens versus F0 $\mathrm{HDM} \cdot \mathrm{F} 2$ Base).

Figure 7. Unique genes are differentially methylated in vagal ganglia neurons after allergen sensitization in offspring of HDM-exposed founders.

DMR-associated genes in vagal ganglia neurons were compared between HDMsensitized F2 mice from HDM-exposed founders and HDM-sensitized F2 mice from vehicle-exposed founders (A) Twenty one genes were shared between F0 Veh•F2 Sens and F0 HDM•F2 Sens groups, out of 222 total genes in F0 Veh•F2 Sens mice and 413 total genes in F0 HDM•F2 Sens mice. (B) Of these 21 genes, only 7 had a matching pattern of hyper- or hypomethylated between lineages.

\section{TABLES}

Table 1. Pathway analysis of differentially methylated regions (DMR) and cytosines (DMC) in airway epithelium of second-generation mice. Pathways enriched in DMRs and genes associated with each pathway are denoted in bold font. All pathways identified in DMR analysis were similarly identified in DMC 
analysis. Additional pathways were identified in DMC analysis, denoted in italics, with associated genes.

Table 2. Over-represented transcription factor binding sites in DMRs of airway epithelium and sensory neurons from F2 mice before and after allergen sensitization.

Table 3. Pathway analysis of differentially methylated regions (DMR) and cytosines (DMC) in vagal ganglia of second-generation mice. Pathways enriched in DMRs and genes associated with each pathway are denoted in bold font. All pathways identified in DMR analysis were similarly identified in DMC analysis. Additional pathways were identified in DMC analysis, denoted in italics, with associated genes. 


\section{SUPPLEMENTARY FIGURE LEGEND}

\section{Supplementary Figure 1. Grandmaternal allergen exposure regulates differentially methylated cytosines in airway epithelium of second-generation offspring at} baseline and after allergen sensitization. Maternal HDM exposure alone resulted in 1,390 DMCs in airway epithelium of F2 offspring (F0 HDM•F2 Base vs F0 Veh•F2 Base). F2 HDM sensitization alone resulted in 1,467 DMCs (F0Veh•F2Sens vs F0 Veh॰F2 Base). In contrast, HDM sensitization in F2 mice from HDM-exposed founders resulted in 3,756 total DMCs (F0 HDM•F2 Sens vs F0 HDM•F2 Base).

\section{Supplementary Figure 2. Grandmaternal allergen exposure regulates vagal} ganglia cytosine methylation in second-generation offspring at baseline and after allergen sensitization. Grandmaternal HDM exposure alone resulted in 901 DMCs (F0 $\mathrm{HDM} \cdot \mathrm{F} 2$ Base vs F0 Veh•F2 Base). F2 HDM sensitization alone resulted in 1,467 DMCs (FOVeh•F2Sens vs F0 Veh•F2 Base). In contrast, HDM sensitization in F2 mice from HDM-exposed maternal founders resulted in 1,787 total DMCs (F0 HDM•F2 Sens vs F0 HDM•F2 Base).

\section{Supplementary Figure 3. Gene ontology analysis of biological process enrichment in vagal ganglia from second-generation offspring.}

Gene ontology analysis of DMCs in vagal ganglia of F2 mice identified enriched biological processes (individual small circles), which were then grouped based on functional annotation using Cytoscape Enrichment Map (larger, labeled, black circles). Each small circle represents an individual biological process and size is proportional to number of involved genes, while connecting edges represent shared genes between individual biological processes. (A) Gene ontology analysis showing effects of HDM sensitization on biological process enrichment in F2 offspring from vehicle-exposed F0 mice (F0 Veh॰F2 Sens vs F0 VEH•F2 Base). (B) Gene ontology analysis showing potentiating effects of $\mathrm{F} 0$ grandmaternal HDM exposure on biological process enrichment in F2 mice after HDM sensitization (F0 HDM•F2 Sens vs F0 HDM•F2 Base). 


\section{REFERENCES:}

ADCOCK, I. M., LANE, S. J., BROWN, C. R., LEE, T. H. \& BARNES, P. J. 1995. Abnormal glucocorticoid receptor-activator protein 1 interaction in steroid-resistant asthma. $J$ Exp Med, 182, 1951-8.

ADVENIER, C., SARRIA, B., NALINE, E., PUYBASSET, L. \& LAGENTE, V. 1990. Contractile activity of three endothelins (ET-1, ET-2 and ET-3) on the human isolated bronchus. Br J Pharmacol, 100, 168-72.

AKALIN, A., FRANKE, V., VLAHOVICEK, K., MASON, C. E. \& SCHUBELER, D. 2015. Genomation: a toolkit to summarize, annotate and visualize genomic intervals. Bioinformatics, 31, 1127-9.

AKALIN, A., KORMAKSSON, M., LI, S., GARRETT-BAKELMAN, F. E., FIGUEROA, M. E., MELNICK, A. \& MASON, C. E. 2012. methylKit: a comprehensive R package for the analysis of genome-wide DNA methylation profiles. Genome Biol, 13, R87.

ALLAN, R. S., ZUEVA, E., CAMMAS, F., SCHREIBER, H. A., MASSON, V., BELZ, G. T., ROCHE, D., MAISON, C., QUIVY, J. P., ALMOUZNI, G. \& AMIGORENA, S. 2012. An epigenetic silencing pathway controlling T helper 2 cell lineage commitment. Nature, 487, 249-53.

BALAGUER, L., ROMANO, J. \& RUIZ-PESINI, P. 1992. Localization of serotonin, cholecystokinin and somatostatin immunoreactivity in the lower respiratory tract of embryonic, foetal and postnatal sheep. Histol Histopathol, 7, 703-8.

BARON, U., FLOESS, S., WIECZOREK, G., BAUMANN, K., GRUTZKAU, A., DONG, J., THIEL, A., BOELD, T. J., HOFFMANN, P., EDINGER, M., TURBACHOVA, I., HAMANN, A., OLEK, S. \& HUEHN, J. 2007. DNA demethylation in the human FOXP3 locus discriminates regulatory T cells from activated FOXP3(+) conventional T cells. Eur J Immunol, 37, 2378-89.

BARTON, S. J., NGO, S., COSTELLO, P., GARRATT, E., EL-HEIS, S., ANTOUN, E., CLARKE-HARRIS, R., MURRAY, R., BHATT, T., BURDGE, G., COOPER, C., INSKIP, H., VAN DER BEEK, E. M., SHEPPARD, A., GODFREY, K. M., LILLYCROP, K. A. \& EPIGEN, C. 2017. DNA methylation of Th2 lineage determination genes at birth is associated with allergic outcomes in childhood. Clin Exp Allergy, 47, 1599-1608.

BOUCHERAT, O., NADEAU, V., BERUBE-SIMARD, F. A., CHARRON, J. \& JEANNOTTE, L. 2014. Crucial requirement of ERK/MAPK signaling in respiratory tract development. Development, 141, 3197-211.

BRENNAN, S. C., FINNEY, B. A., LAZAROU, M., ROSSER, A. E., SCHERF, C., ADRIAENSEN, D., KEMP, P. J. \& RICCARDI, D. 2013. Fetal calcium regulates branching morphogenesis in the developing human and mouse lung: involvement of voltage-gated calcium channels. PLoS One, 8, e80294.

BRUGHA, R., LOWE, R., HENDERSON, A. J., HOLLOWAY, J. W., RAKYAN, V., WOZNIAK, E., MAHMUD, N., SEYMOUR, K., GRIGG, J. \& SHAHEEN, S. O. 2017. DNA methylation profiles between airway epithelium and proxy tissues in children. Acta Paediatr, 106, 2011-2016.

CARBONE, L., DAVIS, B. A., FEI, S. S., WHITE, A., NEVONEN, K. A., TAKAHASHI, D., VINSON, A., TRUE, C., ROBERTS, C. T., JR. \& VARLAMOV, O. 2019. Synergistic Effects of Hyperandrogenemia and Obesogenic Western-style Diet on Transcription and DNA Methylation in Visceral Adipose Tissue of Nonhuman Primates. Sci Rep, 9, 19232. 
CARDENAS, A., SORDILLO, J. E., RIFAS-SHIMAN, S. L., CHUNG, W., LIANG, L., COULL, B. A., HIVERT, M. F., LAI, P. S., FORNO, E., CELEDON, J. C., LITONJUA, A. A., BRENNAN, K. J., DEMEO, D. L., BACCARELLI, A. A., OKEN, E. \& GOLD, D. R. 2019. The nasal methylome as a biomarker of asthma and airway inflammation in children. Nat Commun, 10, 3095.

CHATZI, L., TORRENT, M., ROMIEU, I., GARCIA-ESTEBAN, R., FERRER, C., VIOQUE, J., KOGEVINAS, M. \& SUNYER, J. 2008. Mediterranean diet in pregnancy is protective for wheeze and atopy in childhood. Thorax, 63, 507-13.

CHOY, D. F., MODREK, B., ABBAS, A. R., KUMMERFELD, S., CLARK, H. F., WU, L. C., FEDOROWICZ, G., MODRUSAN, Z., FAHY, J. V., WOODRUFF, P. G. \& ARRON, J. R. 2011. Gene expression patterns of Th2 inflammation and intercellular communication in asthmatic airways. J Immunol, 186, 1861-9.

COHEN, E. D., IHIDA-STANSBURY, K., LU, M. M., PANETTIERI, R. A., JONES, P. L. \& MORRISEY, E. E. 2009. Wnt signaling regulates smooth muscle precursor development in the mouse lung via a tenascin C/PDGFR pathway. J Clin Invest, 119, 2538-49.

DEAN, C. H., MILLER, L. A., SMITH, A. N., DUFORT, D., LANG, R. A. \& NISWANDER, L. A. 2005. Canonical Wnt signaling negatively regulates branching morphogenesis of the lung and lacrimal gland. Dev Biol, 286, 270-86.

DEN DEKKER, H. T., BURROWS, K., FELIX, J. F., SALAS, L. A., NEDELJKOVIC, I., YAO, J., RIFAS-SHIMAN, S. L., RUIZ-ARENAS, C., AMIN, N., BUSTAMANTE, M., DEMEO, D. L., HENDERSON, A. J., HOWE, C. G., HIVERT, M. F., IKRAM, M. A., DE JONGSTE, J. C., LAHOUSSE, L., MANDAVIYA, P. R., VAN MEURS, J. B., PINART, M., SHARP, G. C., STOLK, L., UITTERLINDEN, A. G., ANTO, J. M., LITONJUA, A. A., BRETON, C. V., BRUSSELlE, G. G., SUNYER, J., SMITH, G. D., RELTON, C. L., JADDOE, V. W. V. \& DUIJTS, L. 2019. Newborn DNA-methylation, childhood lung function, and the risks of asthma and COPD across the life course. Eur Respir J, 53.

DEVRIES, A. \& VERCELLI, D. 2016. Epigenetic Mechanisms in Asthma. Ann Am Thorac Soc, 13 Suppl 1, S48-50.

DEVRIES, A., WLASIUK, G., MILLER, S. J., BOSCO, A., STERN, D. A., LOHMAN, I. C., ROTHERS, J., JONES, A. C., NICODEMUS-JOHNSON, J., VASQUEZ, M. M., CURTIN, J. A., SIMPSON, A., CUSTOVIC, A., JACKSON, D. J., GERN, J. E., LEMANSKE, R. F., JR., GUERRA, S., WRIGHT, A. L., OBER, C., HALONEN, M. \& VERCELLI, D. 2017. Epigenome-wide analysis links SMAD3 methylation at birth to asthma in children of asthmatic mothers. J Allergy Clin Immunol, 140, 534-542.

DRAKE, M. G., COOK, M., FRYER, A. D., JACOBY, D. B. \& SCOTT, G. D. 2021. Airway Sensory Nerve Plasticity in Asthma and Chronic Cough. Front Physiol, 12, 720538.

DRAKE, M. G., SCOTT, G. D., BLUM, E. D., LEBOLD, K. M., NIE, Z., LEE, J. J., FRYER, A. D., COSTELLO, R. W. \& JACOBY, D. B. 2018. Eosinophils increase airway sensory nerve density in mice and in human asthma. Sci Transl Med, 10.

EVERSON, T. M., LYONS, G., ZHANG, H., SOTO-RAMIREZ, N., LOCKETT, G. A., PATIL, V. K., MERID, S. K., SODERHALL, C., MELEN, E., HOLLOWAY, J. W., ARSHAD, S. H. \& KARMAUS, W. 2015. DNA methylation loci associated with atopy and high serum IgE: a genome-wide application of recursive Random Forest feature selection. Genome Med, 7, 89. 
FAURA TELLEZ, G., VANDEPOELE, K., BROUWER, U., KONING, H., ELDERMAN, R. M., HACKETT, T. L., WILLEMSE, B. W., HOLLOWAY, J., VAN ROY, F., KOPPELMAN, G. H. \& NAWIJN, M. C. 2015. Protocadherin-1 binds to SMAD3 and suppresses TGF-beta1-induced gene transcription. Am J Physiol Lung Cell Mol Physiol, 309, L725-35.

FERREIRA, M. A. R., VONK, J. M., BAURECHT, H., MARENHOLZ, I., TIAN, C., HOFFMAN, J. D., HELMER, Q., TILLANDER, A., ULLEMAR, V., LU, Y., GROSCHE, S., RUSCHENDORF, F., GRANELL, R., BRUMPTON, B. M., FRITSCHE, L. G., BHATTA, L., GABRIELSEN, M. E., NIELSEN, J. B., ZHOU, W., HVEEM, K., LANGHAMMER, A., HOLMEN, O. L., LOSET, M., ABECASIS, G. R., WILLER, C. J., EMAMI, N. C., CAVAZOS, T. B., WITTE, J. S., SZWAJDA, A., ANDME RESEARCH, T., COLLABORATORS OF THE, S. S., HINDS, D. A., HUBNER, N., WEIDINGER, S., MAGNUSSON, P. K., JORGENSON, E., KARLSSON, R., PATERNOSTER, L., BOOMSMA, D. I., ALMQVIST, C., LEE, Y. A. \& KOPPELMAN, G. H. 2020. Age-of-onset information helps identify 76 genetic variants associated with allergic disease. PLoS Genet, 16, e1008725.

FIELDS, P. E., KIM, S. T. \& FLAVELL, R. A. 2002. Cutting edge: changes in histone acetylation at the IL-4 and IFN-gamma loci accompany Th1/Th2 differentiation. $J$ Immunol, 169, 647-50.

FINSNES, F., CHRISTENSEN, G., LYBERG, T., SEJERSTED, O. M. \& SKJONSBERG, O. H. 1998. Increased synthesis and release of endothelin-1 during the initial phase of airway inflammation. Am J Respir Crit Care Med, 158, 1600-6.

FINSNES, F., SKJONSBERG, O. H., TONNESSEN, T., NAESS, O., LYBERG, T. \& CHRISTENSEN, G. 1997. Endothelin production and effects of endothelin antagonism during experimental airway inflammation. Am J Respir Crit Care Med, 155, 1404-12.

FRANK, D. B., PENG, T., ZEPP, J. A., SNITOW, M., VINCENT, T. L., PENKALA, I. J., CUI, Z., HERRIGES, M. J., MORLEY, M. P., ZHOU, S., LU, M. M. \& MORRISEY, E. E. 2016. Emergence of a Wave of Wnt Signaling that Regulates Lung Alveologenesis by Controlling Epithelial Self-Renewal and Differentiation. Cell Rep, 17, 2312-2325.

GHEORGHE, C. P., GOYAL, R., MITTAL, A. \& LONGO, L. D. 2010. Gene expression in the placenta: maternal stress and epigenetic responses. Int J Dev Biol, 54, 507-23.

GILLILAND, F. D., BERHANE, K., MCCONNELL, R., GAUDERMAN, W. J., VORA, H., RAPPAPORT, E. B., AVOL, E. \& PETERS, J. M. 2000. Maternal smoking during pregnancy, environmental tobacco smoke exposure and childhood lung function. Thorax, 55, 271-6.

GREGORY, D. J., KOBZIK, L., YANG, Z., MCGUIRE, C. C. \& FEDULOV, A. V. 2017. Transgenerational transmission of asthma risk after exposure to environmental particles during pregnancy. Am J Physiol Lung Cell Mol Physiol, 313, L395-L405.

GUNAWARDHANA, L. P., BAINES, K. J., MATTES, J., MURPHY, V. E., SIMPSON, J. L. \& GIBSON, P. G. 2014. Differential DNA methylation profiles of infants exposed to maternal asthma during pregnancy. Pediatr Pulmonol, 49, 852-62.

GUNGL, A., BIASIN, V., WILHELM, J., OLSCHEWSKI, A., KWAPISZEWSKA, G. \& MARSH, L. M. 2018. Fra2 Overexpression in Mice Leads to Non-allergic Asthma Development in an IL-13 Dependent Manner. Front Immunol, 9, 2018.

HAN, L., KAUSHAL, A., ZHANG, H., KADALAYIL, L., DUAN, J., HOLLOWAY, J. W., KARMAUS, W., BANERJEE, P., TSAI, S. F., WEN, H. J., ARSHAD, S. H. \& WANG, 
S. L. 2021. DNA Methylation at Birth is Associated with Childhood Serum Immunoglobulin E Levels. Epigenet Insights, 14, 25168657211008108.

HEINZ, S., BENNER, C., SPANN, N., BERTOLINO, E., LIN, Y. C., LASLO, P., CHENG, J. X., MURRE, C., SINGH, H. \& GLASS, C. K. 2010. Simple combinations of lineagedetermining transcription factors prime cis-regulatory elements required for macrophage and B cell identities. Mol Cell, 38, 576-89.

HINDS, D. A., MCMAHON, G., KIEFER, A. K., DO, C. B., ERIKSSON, N., EVANS, D. M., ST POURCAIN, B., RING, S. M., MOUNTAIN, J. L., FRANCKE, U., DAVEYSMITH, G., TIMPSON, N. J. \& TUNG, J. Y. 2013. A genome-wide association metaanalysis of self-reported allergy identifies shared and allergy-specific susceptibility loci. Nat Genet, 45, 907-11.

HOSOKAWA, H., KATO, M., TOHYAMA, H., TAMAKI, Y., ENDO, Y., KIMURA, M. Y., TUMES, D. J., MOTOHASHI, S., MATSUMOTO, M., NAKAYAMA, K. I., TANAKA, T. \& NAKAYAMA, T. 2015. Methylation of Gata3 protein at Arg-261 regulates transactivation of the Il5 gene in T helper 2 cells. J Biol Chem, 290, 13095-103.

HYLKEMA, M. N. \& BLACQUIERE, M. J. 2009. Intrauterine effects of maternal smoking on sensitization, asthma, and chronic obstructive pulmonary disease. Proc Am Thorac Soc, 6, 660-2.

JACQUES, E., SEMLALI, A., BOULET, L. P. \& CHAKIR, J. 2010. AP-1 overexpression impairs corticosteroid inhibition of collagen production by fibroblasts isolated from asthmatic subjects. Am J Physiol Lung Cell Mol Physiol, 299, L281-7.

JAKOBI, M., KIEFER, A., MIRZAKHANI, H., RAUH, M., ZIMMERMANN, T., XEPAPADAKI, P., STANIC, B., AKDIS, M., PAPADOPOULOS, N. G., RABY, B. A., WEISS, S. T. \& FINOTTO, S. 2020. Role of nuclear factor of activated T cells 2 (NFATc2) in allergic asthma. Immun Inflamm Dis, 8, 704-712.

JEONG, J. S., LEE, K. B., KIM, S. R., KIM, D. I., PARK, H. J., LEE, H. K., KIM, H. J., CHO, S. H., KOLLIPUTI, N., KIM, S. H. \& LEE, Y. C. 2018. Airway epithelial phosphoinositide 3-kinase-delta contributes to the modulation of fungi-induced innate immune response. Thorax, 73, 758-768.

JOUBERT, B. R., FELIX, J. F., YOUSEFI, P., BAKULSKI, K. M., JUST, A. C., BRETON, C., REESE, S. E., MARKUNAS, C. A., RICHMOND, R. C., XU, C. J., KUPERS, L. K., OH, S. S., HOYO, C., GRUZIEVA, O., SODERHALL, C., SALAS, L. A., BAIZ, N., ZHANG, H., LEPEULE, J., RUIZ, C., LIGTHART, S., WANG, T., TAYLOR, J. A., DUIJTS, L., SHARP, G. C., JANKIPERSADSING, S. A., NILSEN, R. M., VAEZ, A., FALLIN, M. D., HU, D., LITONJUA, A. A., FUEMMELER, B. F., HUEN, K., KERE, J., KULL, I., MUNTHE-KAAS, M. C., GEHRING, U., BUSTAMANTE, M., SAURELCOUBIZOLLES, M. J., QURAISHI, B. M., REN, J., TOST, J., GONZALEZ, J. R., PETERS, M. J., HABERG, S. E., XU, Z., VAN MEURS, J. B., GAUNT, T. R., KERKHOF, M., CORPELEIJN, E., FEINBERG, A. P., ENG, C., BACCARELLI, A. A., BENJAMIN NEELON, S. E., BRADMAN, A., MERID, S. K., BERGSTROM, A., HERCEG, Z., HERNANDEZ-VARGAS, H., BRUNEKREEF, B., PINART, M., HEUDE, B., EWART, S., YAO, J., LEMONNIER, N., FRANCO, O. H., WU, M. C., HOFMAN, A., MCARDLE, W., VAN DER VLIES, P., FALAHI, F., GILLMAN, M. W., BARCELLOS, L. F., KUMAR, A., WICKMAN, M., GUERRA, S., CHARLES, M. A., HOLlOWAY, J., AUFFRAY, C., TIEMEIER, H. W., SMITH, G. D., POSTMA, D., HIVERT, M. F., ESKENAZI, B., VRIJHEID, M., ARSHAD, H., ANTO, J. M., 
DEHGHAN, A., KARMAUS, W., ANNESI-MAESANO, I., SUNYER, J., GHANTOUS, A., PERSHAGEN, G., HOLLAND, N., MURPHY, S. K., DEMEO, D. L., BURCHARD, E. G., LADD-ACOSTA, C., SNIEDER, H., NYSTAD, W., et al. 2016. DNA Methylation in Newborns and Maternal Smoking in Pregnancy: Genome-wide Consortium Meta-analysis. Am J Hum Genet, 98, 680-96.

KAELBERER, M. M., CACERES, A. I. \& JORDT, S. E. 2020. Activation of a nerve injury transcriptional signature in airway-innervating sensory neurons after lipopolysaccharideinduced lung inflammation. Am J Physiol Lung Cell Mol Physiol, 318, L953-L964.

KHAKZAD, M. R., MIRSADRAEE, M., MOHAMMADPOUR, A., GHAFARZADEGAN, K., HADI, R., SAGHARI, M. \& MESHKAT, M. 2012. Effect of verapamil on bronchial goblet cells of asthma: an experimental study on sensitized animals. Pulm Pharmacol Ther, 25, 163-8.

KIM, J. S., SHIN, I. S., SHIN, N. R., NAM, J. Y. \& KIM, C. 2020a. Genomewide analysis of DNA methylation and gene expression changes in an ovalbumininduced asthma mouse model. Mol Med Rep, 22, 1709-1716.

KIM, S. R., PARK, H. J., LEE, K. B., KIM, H. J., JEONG, J. S., CHO, S. H. \& LEE, Y. C. 2020b. Epithelial PI3K-delta Promotes House Dust Mite-Induced Allergic Asthma in NLRP3 Inflammasome-Dependent and -Independent Manners. Allergy Asthma Immunol Res, 12, 338-358.

KONIGSHOFF, M. \& EICKELBERG, O. 2010. WNT signaling in lung disease: a failure or a regeneration signal? Am J Respir Cell Mol Biol, 42, 21-31.

KOPPELMAN, G. H., MEYERS, D. A., HOWARD, T. D., ZHENG, S. L., HAWKINS, G. A., AMPLEFORD, E. J., XU, J., KONING, H., BRUINENBERG, M., NOLTE, I. M., VAN DIEMEN, C. C., BOEZEN, H. M., TIMENS, W., WHITTAKER, P. A., STINE, O. C., BARTON, S. J., HOLLOWAY, J. W., HOLGATE, S. T., GRAVES, P. E., MARTINEZ, F. D., VAN OOSTERHOUT, A. J., BLEECKER, E. R. \& POSTMA, D. S. 2009.

Identification of PCDH1 as a novel susceptibility gene for bronchial hyperresponsiveness. Am J Respir Crit Care Med, 180, 929-35.

KOZU, Y., GON, Y., MARUOKA, S., KAZUMICHI, K., SEKIYAMA, A., KISHI, H., NOMURA, Y., IKEDA, M. \& HASHIMOTO, S. 2015. Protocadherin-1 is a glucocorticoid-responsive critical regulator of airway epithelial barrier function. $B M C$ Pulm Med, 15, 80.

KRUEGER, F. \& ANDREWS, S. R. 2011. Bismark: a flexible aligner and methylation caller for Bisulfite-Seq applications. Bioinformatics, 27, 1571-2.

LAMBRECHT, B. N. \& HAMMAD, H. 2012. The airway epithelium in asthma. Nat Med, 18, 684-92.

LANE, S. J., ADCOCK, I. M., RICHARDS, D., HAWRYLOWICZ, C., BARNES, P. J. \& LEE, T. H. 1998. Corticosteroid-resistant bronchial asthma is associated with increased c-fos expression in monocytes and T lymphocytes. J Clin Invest, 102, 2156-64.

LEBOLD, K. M., DRAKE, M. G., HALES-BECK, L. B., FRYER, A. D. \& JACOBY, D. B. 2019. IL-5 Exposure in utero Increases Lung Nerve Density and Causes Airway Reactivity in Adult Offspring. Am J Respir Cell Mol Biol.

LEE, K. S., LEE, H. K., HAYFLICK, J. S., LEE, Y. C. \& PURI, K. D. 2006. Inhibition of phosphoinositide 3-kinase delta attenuates allergic airway inflammation and hyperresponsiveness in murine asthma model. FASEB J, 20, 455-65. 
LI, Y. F., LANGHOLZ, B., SALAM, M. T. \& GILLILAND, F. D. 2005. Maternal and grandmaternal smoking patterns are associated with early childhood asthma. Chest, 127, 1232-41.

LIM, R. H., KOBZIK, L. \& DAHL, M. 2010. Risk for asthma in offspring of asthmatic mothers versus fathers: a meta-analysis. PLoS One, 5, e10134.

LIN, P. I., SHU, H. \& MERSHA, T. B. 2020. Comparing DNA methylation profiles across different tissues associated with the diagnosis of pediatric asthma. Sci Rep, 10, 151.

LIU, C., LU, J., TAN, J., LI, L. \& HUANG, B. 2004. Human interleukin-5 expression is synergistically regulated by histone acetyltransferase $\mathrm{CBP} / \mathrm{p} 300$ and transcription factors C/EBP, NF-AT and AP-1. Cytokine, 27, 93-100.

LIU, C., XIANG, Y., LIU, H., LI, Y., TAN, Y., ZHU, X., ZENG, D., LI, M., ZHANG, L. \& QIN, X. 2010. Integrin beta4 was downregulated on the airway epithelia of asthma patients. Acta Biochim Biophys Sin (Shanghai), 42, 538-47.

LIU, C., YUAN, L., ZOU, Y., YANG, M., CHEN, Y., QU, X., LIU, H., JIANG, J., XIANG, Y. \& QIN, X. 2018. ITGB4 is essential for containing HDM-induced airway inflammation and airway hyperresponsiveness. J Leukoc Biol, 103, 897-908.

LIU, J., BALLANEY, M., AL-ALEM, U., QUAN, C., JIN, X., PERERA, F., CHEN, L. C. \& MILLER, R. L. 2008. Combined inhaled diesel exhaust particles and allergen exposure alter methylation of T helper genes and IgE production in vivo. Toxicol Sci, 102, 76-81.

MAMMOTO, T., CHEN, J., JIANG, E., JIANG, A., SMITH, L. E., INGBER, D. E. \& MAMMOTO, A. 2012. LRP5 regulates development of lung microvessels and alveoli through the angiopoietin-Tie2 pathway. PLoS One, 7, e41596.

MOHEIMANI, F., ROTH, H. M., CROSS, J., REID, A. T., SHAHEEN, F., WARNER, S. M., HIROTA, J. A., KICIC, A., HALLSTRAND, T. S., KAHN, M., STICK, S. M., HANSBRO, P. M., HACKETT, T. L. \& KNIGHT, D. A. 2015. Disruption of betacatenin/CBP signaling inhibits human airway epithelial-mesenchymal transition and repair. Int J Biochem Cell Biol, 68, 59-69.

MORTEN, M., COLLISON, A., MURPHY, V. E., BARKER, D., OLDMEADOW, C., ATTIA, J., MEREDITH, J., POWELL, H., ROBINSON, P. D., SLY, P. D., GIBSON, P. G. \& MATTES, J. 2018. Managing Asthma in Pregnancy (MAP) trial: FENO levels and childhood asthma. J Allergy Clin Immunol, 142, 1765-1772 e4.

MORTENSEN, L. J., KREINER-MOLLER, E., HAKONARSON, H., BONNELYKKE, K. \& BISGAARD, H. 2014. The PCDH1 gene and asthma in early childhood. Eur Respir J, 43, 792-800.

OHSHIMA, Y., YASUTOMI, M., OMATA, N., YAMADA, A., FUJISAWA, K., KASUGA, K., HIRAOKA, M. \& MAYUMI, M. 2002. Dysregulation of IL-13 production by cord blood CD4+ T cells is associated with the subsequent development of atopic disease in infants. Pediatr Res, 51, 195-200.

PAASO, E. M., JAAKKOLA, M. S., RANTALA, A. K., HUGG, T. T. \& JAAKKOLA, J. J. 2014. Allergic diseases and asthma in the family predict the persistence and onset-age of asthma: a prospective cohort study. Respir Res, 15, 152.

PALLER, A. S., SPERGEL, J. M., MINA-OSORIO, P. \& IRVINE, A. D. 2019. The atopic march and atopic multimorbidity: Many trajectories, many pathways. J Allergy Clin Immunol, 143, 46-55.

PATIL, V. K., HOLLOWAY, J. W., ZHANG, H., SOTO-RAMIREZ, N., EWART, S., ARSHAD, S. H. \& KARMAUS, W. 2013. Interaction of prenatal maternal smoking, 
interleukin 13 genetic variants and DNA methylation influencing airflow and airway reactivity. Clin Epigenetics, 5, 22.

PATTERSON, R. L., BOEHNING, D. \& SNYDER, S. H. 2004. Inositol 1,4,5-trisphosphate receptors as signal integrators. Annu Rev Biochem, 73, 437-65.

PECH, M., WECKMANN, M., KONIG, I. R., FRANKE, A., HEINSEN, F. A., OLIVER, B., RICKLEFS, I., FUCHS, O., RABE, K., HANSEN, G., E, V. M., KOPP, M. V. \& GROUP, A. L.-S. 2018. Rhinovirus infections change DNA methylation and mRNA expression in children with asthma. PLoS One, 13, e0205275.

PENG, C., CARDENAS, A., RIFAS-SHIMAN, S. L., HIVERT, M. F., GOLD, D. R., PLATTSMILLS, T. A., LIN, X., OKEN, E., BACCARELli, A. A., LITONJUA, A. A. \& DEMEO, D. L. 2018. Epigenome-wide association study of total serum immunoglobulin E in children: a life course approach. Clin Epigenetics, 10, 55.

PENG, C., VAN MEEL, E. R., CARDENAS, A., RIFAS-SHIMAN, S. L., SONAWANE, A. R., GLASS, K. R., GOLD, D. R., PLATTS-MILLS, T. A., LIN, X., OKEN, E., HIVERT, M. F., BACCARELLI, A. A., DE JONG, N. W., FELIX, J. F., JADDOE, V. W., DUIJTS, L., LITONJUA, A. A. \& DEMEO, D. L. 2019. Epigenome-wide association study reveals methylation pathways associated with childhood allergic sensitization. Epigenetics, 14, 445-466.

PIJNENBURG, M. W., FREY, U., DE JONGSTE, J. C. \& SAGLANI, S. 2021. Childhood asthma- pathogenesis and phenotypes. Eur Respir $J$.

PULCZINSKI, J. C., SHANG, Y., DAO, T., LIMJUNYAWONG, N., SUN, Q., MITZNER, W., CHENG, R. Y. \& TANG, W. Y. 2021. Multigenerational Epigenetic Regulation of Allergic Diseases: Utilizing an Experimental Dust Mite-Induced Asthma Model. Front Genet, 12, 624561 .

QUINLAN, A. R. \& HALL, I. M. 2010. BEDTools: a flexible suite of utilities for comparing genomic features. Bioinformatics, 26, 841-2.

REESE, S. E., XU, C. J., DEN DEKKER, H. T., LEE, M. K., SIKDAR, S., RUIZ-ARENAS, C., MERID, S. K., REZWAN, F. I., PAGE, C. M., ULLEMAR, V., MELTON, P. E., OH, S. S., YANG, I. V., BURROWS, K., SODERHALL, C., JIMA, D. D., GAO, L., ARATHIMOS, R., KUPERS, L. K., WIELSCHER, M., RZEHAK, P., LAHTI, J., LAPRISE, C., MADORE, A. M., WARD, J., BENNETT, B. D., WANG, T., BELL, D. A., CONSORTIUM, B., VONK, J. M., HABERG, S. E., ZHAO, S., KARLSSON, R., HOLLAMS, E., HU, D., RICHARDS, A. J., BERGSTROM, A., SHARP, G. C., FELIX, J. F., BUSTAMANTE, M., GRUZIEVA, O., MAGUIRE, R. L., GILLILAND, F., BAIZ, N., NOHR, E. A., CORPELEIJN, E., SEBERT, S., KARMAUS, W., GROTE, V., KAJANTIE, E., MAGNUS, M. C., ORTQVIST, A. K., ENG, C., LIU, A. H., KULL, I., JADDOE, V. W. V., SUNYER, J., KERE, J., HOYO, C., ANNESI-MAESANO, I., ARSHAD, S. H., KOLETZKO, B., BRUNEKREEF, B., BINDER, E. B., RAIKKONEN, K., REISCHL, E., HOLLOWAY, J. W., JARVELIN, M. R., SNIEDER, H., KAZMI, N., BRETON, C. V., MURPHY, S. K., PERSHAGEN, G., ANTO, J. M., RELTON, C. L., SCHWARTZ, D. A., BURCHARD, E. G., HUANG, R. C., NYSTAD, W., ALMQVIST, C., HENDERSON, A. J., MELEN, E., DUIJTS, L., KOPPELMAN, G. H. \& LONDON, S. J. 2019. Epigenome-wide meta-analysis of DNA methylation and childhood asthma. $J$ Allergy Clin Immunol, 143, 2062-2074. 
RINAS, U., HORNEFF, G. \& WAHN, V. 1993. Interferon-gamma production by cord-blood mononuclear cells is reduced in newborns with a family history of atopic disease and is independent from cord blood IgE-levels. Pediatr Allergy Immunol, 4, 60-4.

ROAN, F., OBATA-NINOMIYA, K. \& ZIEGLER, S. F. 2019. Epithelial cell-derived cytokines: more than just signaling the alarm. J Clin Invest, 129, 1441-1451.

SEUMOIS, G., CHAVEZ, L., GERASIMOVA, A., LIENHARD, M., OMRAN, N., KALINKE, L., VEDANAYAGAM, M., GANESAN, A. P., CHAWLA, A., DJUKANOVIC, R., ANSEL, K. M., PETERS, B., RAO, A. \& VIJAYANAND, P. 2014. Epigenomic analysis of primary human $\mathrm{T}$ cells reveals enhancers associated with TH2 memory cell differentiation and asthma susceptibility. Nat Immunol, 15, 777-88.

SHARMA, S., TANTISIRA, K., CAREY, V., MURPHY, A. J., LASKY-SU, J., CELEDON, J. C., LAZARUS, R., KLANDERMAN, B., ROGERS, A., SOTO-QUIROS, M., AVILA, L., MARIANI, T., GAEDIGK, R., LEEDER, S., TORDAY, J., WARBURTON, D., RABY, B. \& WEISS, S. T. 2010. A role for Wnt signaling genes in the pathogenesis of impaired lung function in asthma. Am J Respir Crit Care Med, 181, 328-36.

SOUSA, A. R., LANE, S. J., SOH, C. \& LEE, T. H. 1999. In vivo resistance to corticosteroids in bronchial asthma is associated with enhanced phosyphorylation of JUN N-terminal kinase and failure of prednisolone to inhibit JUN N-terminal kinase phosphorylation. $J$ Allergy Clin Immunol, 104, 565-74.

SPALlUTO, C. M., SINGHANIA, A., CELlURA, D., WOELK, C. H., SANCHEZ-ELSNER, T., STAPLES, K. J. \& WILKINSON, T. M. A. 2017. IFN-gamma Influences Epithelial Antiviral Responses via Histone Methylation of the RIG-I Promoter. Am J Respir Cell Mol Biol, 57, 428-438.

STRETTON, C. D. \& BARNES, P. J. 1989. Cholecystokinin-octapeptide constricts guinea-pig and human airways. Br J Pharmacol, 97, 675-82.

TRISCHLER, J., SHIOMI, T., TURNER, D. L., SKLEPKIEWICZ, P. L., GOLDKLANG, M. P., TANAKA, K. F., XU, M., FARBER, D. L. \& D'ARMIENTO, J. M. 2016. Immune Modulation of the T Cell Response in Asthma through Wnt10b. Am J Respir Cell Mol Biol, 54, 584-93.

TRUMP, S., BIEG, M., GU, Z., THURMANN, L., BAUER, T., BAUER, M., ISHAQUE, N., RODER, S., GU, L., HERBERTH, G., LAWERENZ, C., BORTE, M., SCHLESNER, M., PLASS, C., DIESSL, N., ESZLINGER, M., MUCKE, O., ELVERS, H. D., WISSENBACH, D. K., VON BERGEN, M., HERRMANN, C., WEICHENHAN, D., WRIGHT, R. J., LEHMANN, I. \& EILS, R. 2016. Prenatal maternal stress and wheeze in children: novel insights into epigenetic regulation. Sci Rep, 6, 28616.

TULCHINSKY, E. M., GEORGIEV, G. P. \& LUKANIDIN, E. M. 1996. Novel AP-1 binding site created by DNA-methylation. Oncogene, 12, 1737-45.

WARNER, S. M., HACKETT, T. L., SHAHEEN, F., HALLSTRAND, T. S., KICIC, A., STICK, S. M. \& KNIGHT, D. A. 2013. Transcription factor p63 regulates key genes and wound repair in human airway epithelial basal cells. Am J Respir Cell Mol Biol, 49, 97888.

WHITE, G. P., WATT, P. M., HOLT, B. J. \& HOLT, P. G. 2002. Differential patterns of methylation of the IFN-gamma promoter at $\mathrm{CpG}$ and non-CpG sites underlie differences in IFN-gamma gene expression between human neonatal and adult CD45RO- T cells. $J$ Immunol, 168, 2820-7. 
WILKER, E. H., ALEXEEFF, S. E., POON, A., LITONJUA, A. A., SPARROW, D., VOKONAS, P. S., MITTLEMAN, M. A. \& SCHWARTZ, J. 2009. Candidate genes for respiratory disease associated with markers of inflammation and endothelial dysfunction in elderly men. Atherosclerosis, 206, 480-5.

WRIGHT, D. B., MEURS, H. \& DEKKERS, B. G. 2014. Integrins: therapeutic targets in airway hyperresponsiveness and remodelling? Trends Pharmacol Sci, 35, 567-74.

WU, M., YANG, Y., YUAN, L., YANG, M., WANG, L., DU, X., QIN, L., WU, S., XIANG, Y., QU, X., LIU, H., QIN, X. \& LIU, C. 2020. DNA methylation down-regulates integrin beta4 expression in asthmatic airway epithelial cells. Clin Exp Allergy, 50, 1127-1139.

XING, S., SHAO, P., LI, F., ZHAO, X., SEO, W., WHEAT, J. C., RAMASAMY, S., WANG, J., LI, X., PENG, W., YU, S., LIU, C., TANIUCHI, I., SWEETSER, D. A. \& XUE, H. H. 2018. Tle corepressors are differentially partitioned to instruct CD8(+) T cell lineage choice and identity. $J$ Exp Med, 215, 2211-2226.

XU, C. J., SODERHALL, C., BUSTAMANTE, M., BAIZ, N., GRUZIEVA, O., GEHRING, U., MASON, D., CHATZI, L., BASTERRECHEA, M., LLOP, S., TORRENT, M., FORASTIERE, F., FANTINI, M. P., CARLSEN, K. C. L., HAAHTELA, T., MORIN, A., KERKHOF, M., MERID, S. K., VAN RIJKOM, B., JANKIPERSADSING, S. A., BONDER, M. J., BALLEREAU, S., VERMEULEN, C. J., AGUIRRE-GAMBOA, R., DE JONGSTE, J. C., SMIT, H. A., KUMAR, A., PERSHAGEN, G., GUERRA, S., GARCIA-AYMERICH, J., GRECO, D., REINIUS, L., MCEACHAN, R. R. C., AZAD, R., HOVLAND, V., MOWINCKEL, P., ALENIUS, H., FYHRQUIST, N., LEMONNIER, N., PELLET, J., AUFFRAY, C., CONSORTIUM, B., VAN DER VLIES, P., VAN DIEMEN, C. C., LI, Y., WIJMENGA, C., NETEA, M. G., MOFFATT, M. F., COOKSON, W., ANTO, J. M., BOUSQUET, J., LAATIKAINEN, T., LAPRISE, C., CARLSEN, K. H., GORI, D., PORTA, D., INIGUEZ, C., BILBAO, J. R., KOGEVINAS, M., WRIGHT, J., BRUNEKREEF, B., KERE, J., NAWIJN, M. C., ANNESIMAESANO, I., SUNYER, J., MELEN, E. \& KOPPELMAN, G. H. 2018. DNA methylation in childhood asthma: an epigenome-wide meta-analysis. Lancet Respir Med, 6, 379-388.

YANG, I. V., PEDERSEN, B. S., LIU, A., O'CONNOR, G. T., TEACH, S. J., KATTAN, M., MISIAK, R. T., GRUCHALLA, R., STEINBACH, S. F., SZEFLER, S. J., GILL, M. A., CALATRONI, A., DAVID, G., HENNESSY, C. E., DAVIDSON, E. J., ZHANG, W., GERGEN, P., TOGIAS, A., BUSSE, W. W. \& SCHWARTZ, D. A. 2015. DNA methylation and childhood asthma in the inner city. J Allergy Clin Immunol, 136, 69-80.

YANG, I. V., PEDERSEN, B. S., LIU, A. H., O'CONNOR, G. T., PILLAI, D., KATTAN, M., MISIAK, R. T., GRUCHALLA, R., SZEFLER, S. J., KHURANA HERSHEY, G. K., KERCSMAR, C., RICHARDS, A., STEVENS, A. D., KOLAKOWSKI, C. A., MAKHIJA, M., SORKNESS, C. A., KROUSE, R. Z., VISNESS, C., DAVIDSON, E. J., HENNESSY, C. E., MARTIN, R. J., TOGIAS, A., BUSSE, W. W. \& SCHWARTZ, D. A. 2017. The nasal methylome and childhood atopic asthma. J Allergy Clin Immunol, 139, 1478-1488.

YOUNG, S., LE SOUEF, P. N., GEELHOED, G. C., STICK, S. M., TURNER, K. J. \& LANDAU, L. I. 1991. The influence of a family history of asthma and parental smoking on airway responsiveness in early infancy. $N$ Engl J Med, 324, 1168-73. 
YUAN, L., DU, X., TANG, S., WU, S., WANG, L., XIANG, Y., QU, X., LIU, H., QIN, X. \& LIU, C. 2019. ITGB4 deficiency induces senescence of airway epithelial cells through p53 activation. FEBS J, 286, 1191-1203.

ZHANG, M., SHI, J., HUANG, Y. \& LAI, L. 2012. Expression of canonical WNT/betaCATENIN signaling components in the developing human lung. BMC Dev Biol, 12, 21. ZHANG, X., CHEN, X., WEIRAUCH, M. T., ZHANG, X., BURLESON, J. D., BRANDT, E. B. \& JI, H. 2018. Diesel exhaust and house dust mite allergen lead to common changes in the airway methylome and hydroxymethylome. Environ Epigenet, 4, dvy020. 
F0 Generation

$\mathrm{n}=10$ pairs

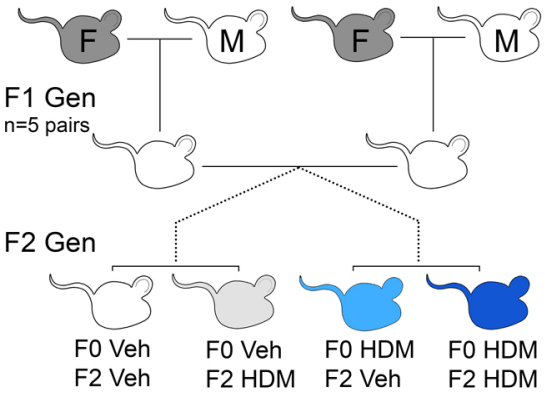

F0 Grandmaternal Sensitization

Day $0-4 \quad 5-6 \quad 25 \quad 25$ - labor $\uparrow \uparrow \uparrow \uparrow \uparrow \uparrow \uparrow \quad \uparrow \quad \uparrow \uparrow \uparrow \uparrow \uparrow \uparrow \uparrow$ HDM Rest Breed HDM Rest $\begin{array}{cc}\begin{array}{c}\text { or } \\ \text { Veh }\end{array} & \begin{array}{c}\text { or } \\ \text { Veh }\end{array} \\ \text { Repeat } \times 3 & \text { Repeat }\end{array}$

F2 Sensitization and Challenge

Day $0-1---T^{---14-17---18}$

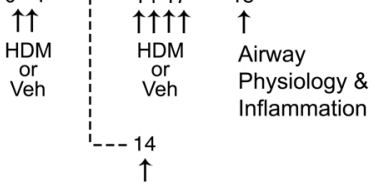

Genome-wide Methylation 
A

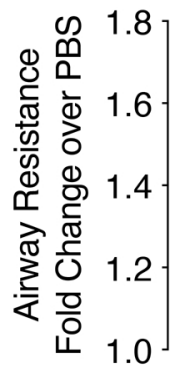

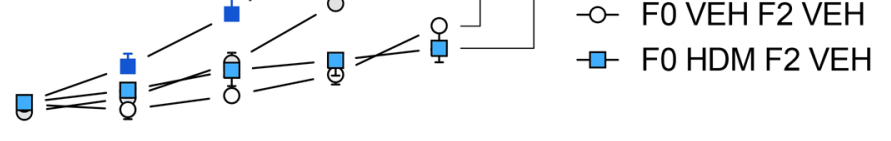

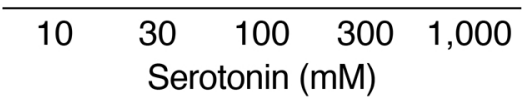

C

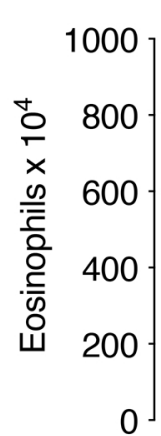

$\frac{\text { VEH HDM }}{\text { FO VEH }} \frac{\text { VEH HDM }}{\text { FO HDM }}$

E

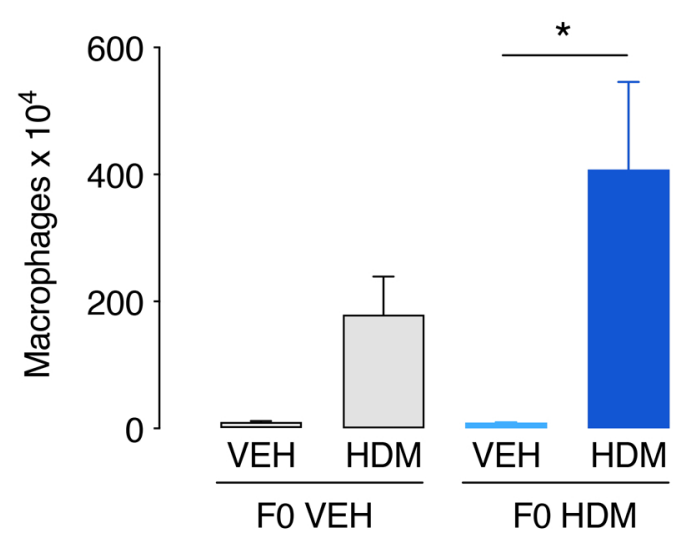

B

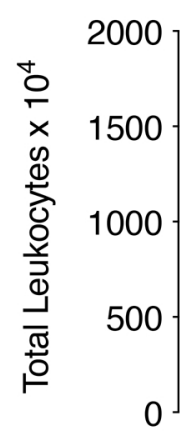

D

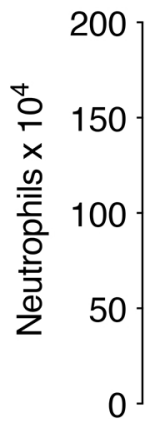

F

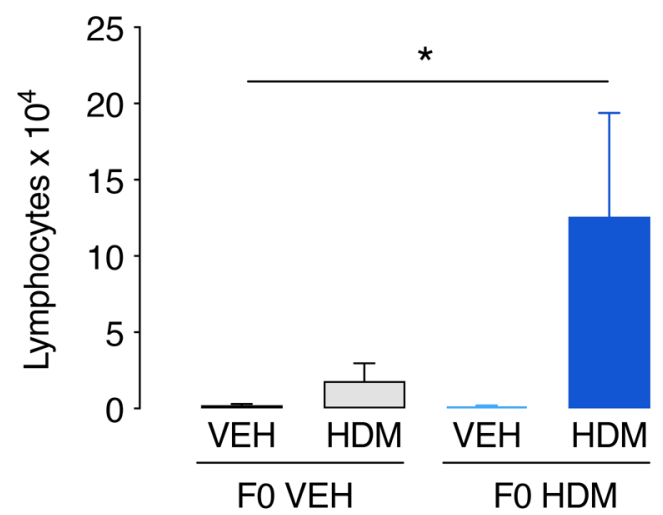



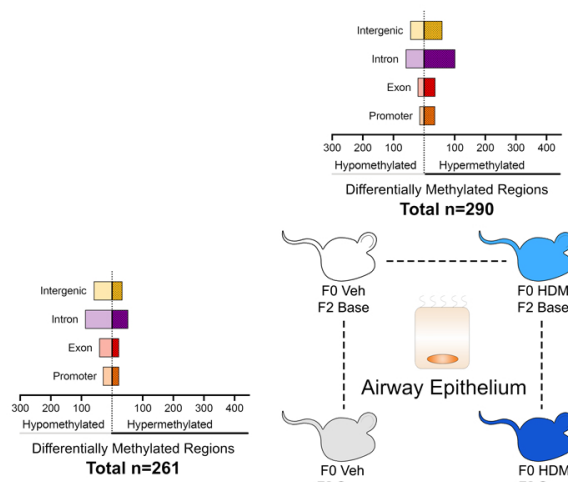

Total $n=290$
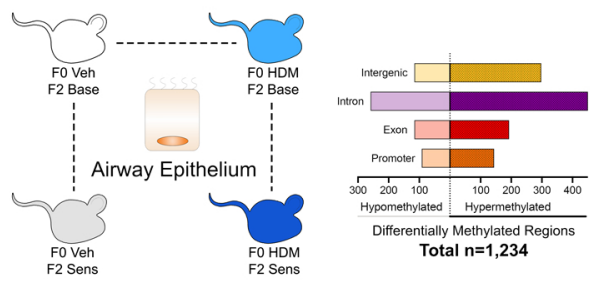


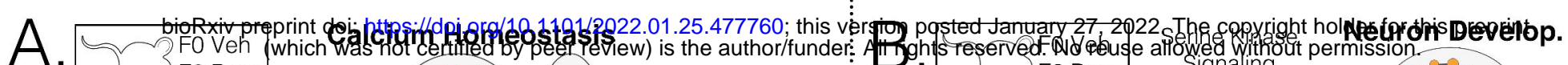
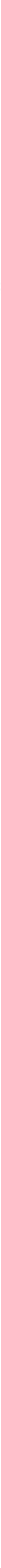


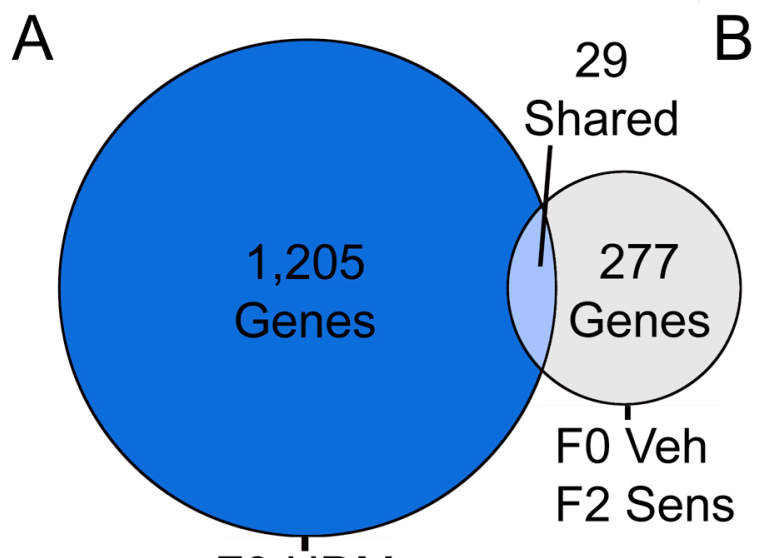

FO HDM

F2 Sens

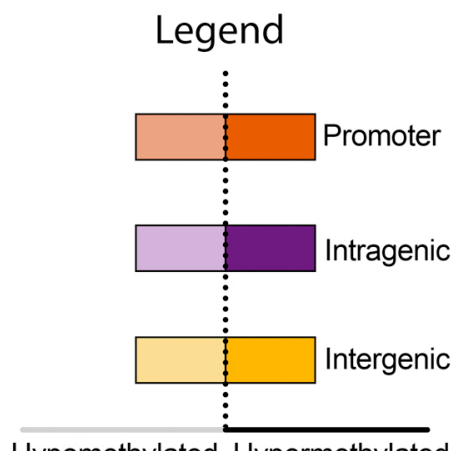

Hypomethylated Hypermethylated

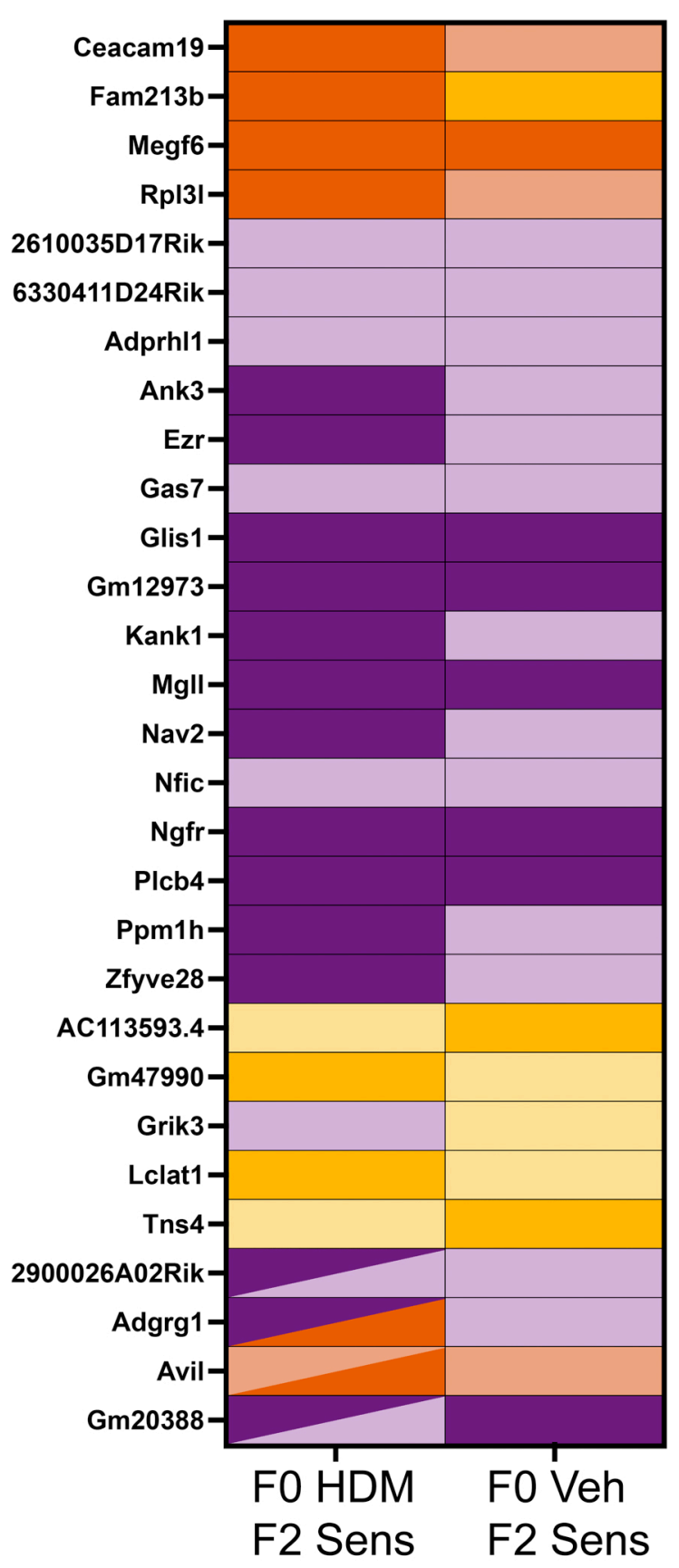




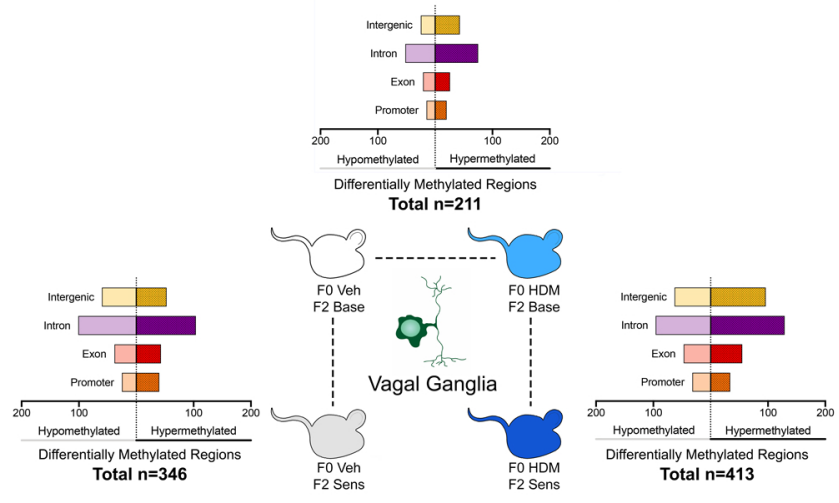


A

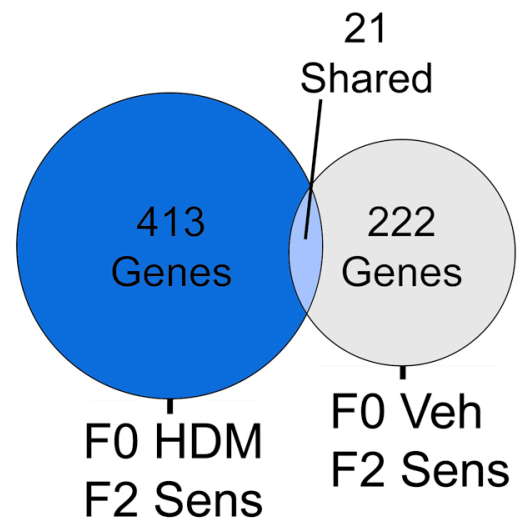

B

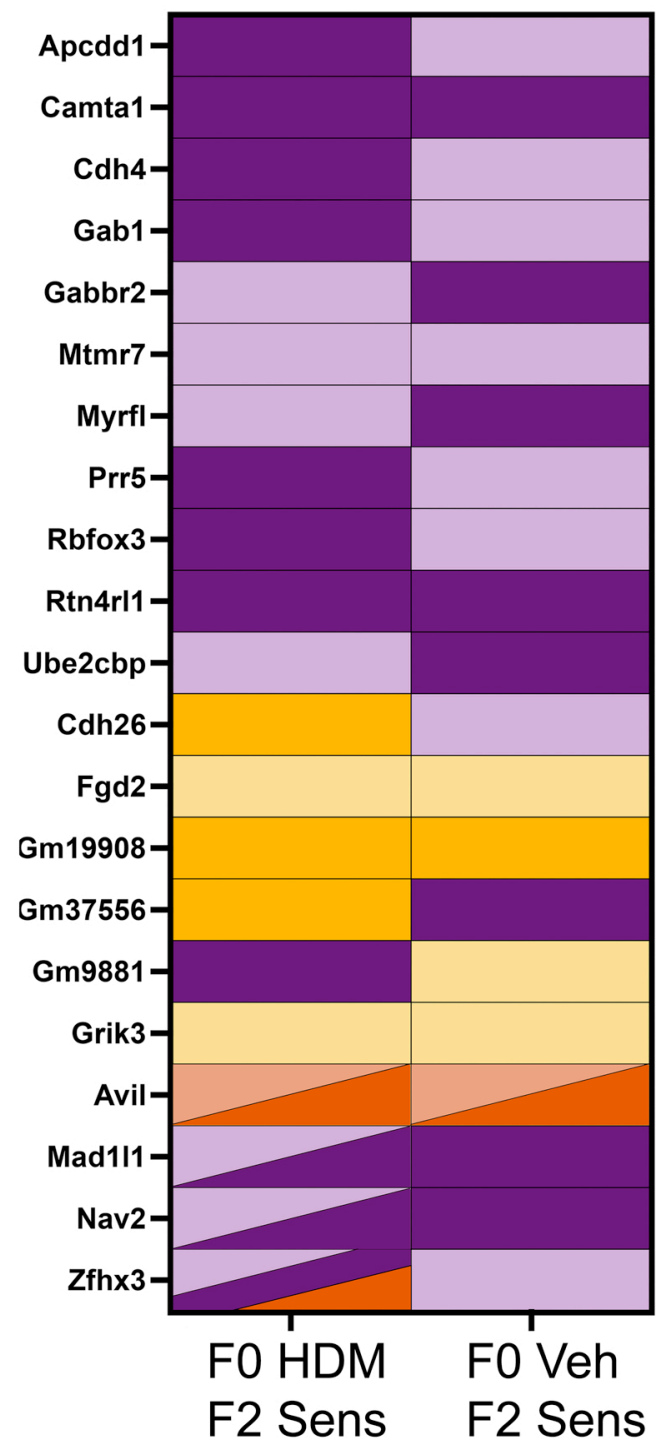

Hypomethylated Hypermethylated

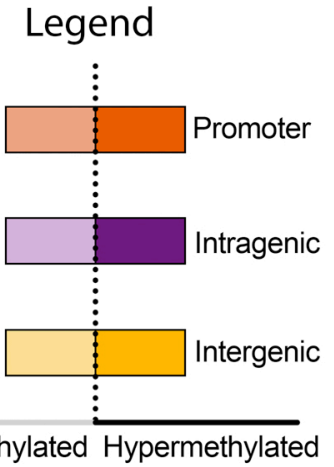


F0 Veh॰F2 Sens vs. F0 Veh•F2 Base

Beta1/2 adrenergic receptor signaling

Oxytocin receptor-mediated signaling

5HT2 type receptor-mediated signaling

Thyrotropin-releasing hormone receptor Integrin signaling

\section{FO HDM•F2 Sens vs. FO HDM•F2 Base}

\section{Endothelin signalin}

Gonadotropin-releasing hormone receptor

Platelet derived growth factor signaling

Wnt signaling

Cholecystokinin signaling

GABA-B receptor II signaling

Histamine $\mathrm{H} 1$ receptor-mediated signaling

Nicotinic acetylcholine receptor signaling

Oxytocin receptor mediated signaling

5HT2 type receptor-mediated signaling
Cacna1c, Cacna1d, Cacnb4, Gngt2

Adcy7, Cacnb1, Cacnb3, Gnb1, Ryr1

Cacna1d, Cacnb1, Cacnb4, Gngt2, Plcb4

Cacnb3, Gnb1, Plcd3, Prkce

Cacna1c, Cacna1d, Cacnb4, Gngt2, Plcb4

10.11

Cacnb1, Cacnb3, Gnb1, Plcd3, Prkce

Cacnb1, Cacnb3, Cacnb4, Gnb1, Gngt2, Plcb4, Plcd3, Prkce

3.63

Abl1, Acta1, Col13a1, Col16a1, Col27a1,Lama1, Col4a1, Elmo1, Elmo2,

2.67

0.049

Itga2b, Itgad, Itgb4, Map3k4, Map3k5, Parvb, Pik3cd, Rapgef1, Src

\section{Adcy1, Adcy4, Adcy5, Ece1, Edn2, Furin, Gna14, Itpr1, Itpr2, Map2k1,}

5.88 $<0.001$

Adcy7, Akt1, Gnaq, Pik3cd, Plcb3, Prkacb, Prkar1b, Prkce

Adcy1, Bmp7, Camk2b, Crtc1, Gnb1, Insr, Itpr1, Itpr2, Ksr1, Map2k1, Nfatc2, Pbx1, Pik3r1, Pitx1, Prkcd, Ppp3ca, Pxn, Smad3, Sp1

Akt1, Cacna1c, Cacna1d, Gata4, Gnaq, Hras, Hspa1a, Inhbb, Lhx2, Map2k6,

Map3k8, Nfatc4, Otx1, Pcp4, Ppp3ca, Prkag2, Prkar1b, Prkce, Smad2, Tgfb1

Arhgap26, Arhgap27, Elf4, Ephb2, Erg, Ets1, Gm42906, Itpr1, Itpr2, Map2k1, Pik3c3, Pik3r1, Pik3r5, Rps6ka1, Vav2

Arid1b, Axin2, Bcl9, Cdh13, Csnk1g3, Dvl1, Fzd5, Fzd10, Gna14, Gnb1, Itpr1, Itpr2, Lrp5, Nfatc2, Nkd1, Pcdh1, Pcdhgb2, Plcb4, Ppp2r5c,

Ppp3ca, Prkcd, Sag, Smarcd1, Tle3, Wnt3a

Acta1, Acte1, Ankrd6, Cdh2, Cdh3, Cdh23, Ctbp1, Fat2, Fzd1, Fzd7, Gm37388, Gnaq, Gng7, Kremen1, Lef1, Myh6, Nfatc4, Pcdhga10, Plcb3, Ppard, Prkce, Tle4, Wnt4, Wnt5a, Wnt5b, Wnt10b

Adcy1, Akt1, Arhgap4, Camkk1, Cck, Foxo3, Gast, Gnb1, Hdac7, Itpr1, Map2k1, Map2k5, Map2k6, Mef2d, Nfatc2, Pik3r1, Plau, Ppp3ca, Prkacb, Prkcd, Prkce, Pxn, Rhoa, Rps6ka1, Sp1, Sp3, Tpcn1

Adcy1, Adcy5, Adcy7, Cacna1g, Gabbr2, Gnb1, Gng11, Gng7, Prkacb, Prkar1b

Itpr1, Gna14, Gnaq, Gnb1, Gng7, Plcb3, Plcb4, Plcd4, Plcl2, Prkcd, Prkce

Acta1, Acte1, Cacna1c, Cacna1d, Cacnb1, Chrnb3, Myo1a, Myo1b, Myo1e, Myo5c, Myo7a, Myo7b, Myo10, Myo15a, Myo15b, Myo19, Myh6, Plekhh3, Slc44a3, Stx1b, Stx4

Cacna1c, Cacna1d, Cacnb1, Gna14, Gnaq, Gnb1, Gng7, Plcb3, Plcb4, Plcd4, PIcl2, Prkcd, Prkce,

Cacna1c, Cacna1d, Cacnb1, Gna14, Gnaq, Gnb1, Gng7, Gng11, PIcb3, PIcb4, PIcd4, Plcl2, Prkcd, Prkce, 


$22.81 \%$

Elk4(ETS)/Hela-Elk4-ChIP-Seq(GSE31477)/Homer Fli1(ETS)/CD8-FLI-ChIP-Seq(GSE20898)/Homer
Elk1(ETS)/Hela-Elk1-ChIP-Seq(GSE31477)/Homer

NRYTTCCGGY NRYTTCCGGH

$33.0 \%$
$55.7 \%$

$32.0 \%$

$22.1 \%$

$10.8 \%$

F0 HDM F2 Base vs F0 HDM F2 Sens

Elk4(ETS)/Hela-Elk4-ChIP-Seq(GSE31477)/Homer AT5G05550(Trihelix)/col-AT5G05550-DAP-Seq(GSE60143)/Homer p73(p53)/Trachea-p73-ChIP-Seq(PRJNA310161)/Homer Atf3(bZIP)/GBM-ATF3-ChIP-Seq(GSE33912)/Home Fos(bZIP)/TSC-Fos-ChIP-Seq(GSE110950)/Homer JunB(bZIP)/DendriticCells-Junb-ChIP-Seq(GSE36099)/Homer AP-1(bZIP)/ThioMac-PU.1-ChIP-Seq(GSE21512)/Homer AATF(bZIP)/Th17-BATF-ChIP-Seq(GSE39756)/Hom Fra2(bZIP)/Striatum-Fra2-ChIP-Seq(GSE43429)/Homer Fra2(bZ2)//(bZ)/BT549-Fra1-ChIP-Seg(GSE46166)/Hom FosI2(bZ1P)/3T311-Fos/2-ChIP-Seg(GSE56872)/Hor Jun-AP1(bZIP)/K562-cJun-ChIP-Seq(GSE31477)/Homer p53(p53)/Saos-p53-ChlP-Seq/Homer

p63(p53)/Keratinocyte-p63-ChIP-Seq(GSE17611)/Homer ETV4(ETS)/HepG2-ETV4-ChIP-Seq(ENCODE)/Homer ELF1(ETS)/Jurkat-ELE1-ChIP-Seq(SRA014231)/Homer Fli1(ETS)/CD8-FLI-ChIP-Seq(GSE20898)/Homer GABPA(ETS)/Jurkat-GABPa-ChIP-Seq(GSE17954)/Homer Bach2(bZIP)/OCILY7-BaC2-ChP-Seq(GSE44420)/Homer BBFox/Hert-RBFox2-CUP-Seq(GSE57926)/Homer

SUT1/SacCer-Promoters/Homer

AT1G76870(Trihelix)/col-AT1G76870-DAP-Seg(GSE60143)/Homer AT3G58630(Trihelix)/col-AT3G58630-DAP-Se(GSE60143)/Homer Otx2(Homeobox)/EpiLC-Otx2-ChIP-Seq(GSE56098)/Homer AT5G25475(ABI3VP1)/col-AT5G25475-DAP-Seq(GSE60143)/Homer Tcfcp211(CP2)/mES-Tcfcp211-ChIP-Seq(GSE11431)/Home

Pax8(Paired,Homeobox)/Thyroid-Pax8-ChlP-Seg(GSE26938)/Homer PAX5(Paired,Homeobox)/GM12878-PAX5-ChP-Seq(GSE32465)/Her LBD13(LOBAS2)/colamp-LBD13-DAP-Seq(GSE60143)/Homer RAP211(AP2EREBP)/colamp-RAP211-DAP-Seq(GSE60143)/Homer At2g41835(C2H2)/col-At2g41835-DAP-Seq(GSE60143)/Homer

NRYTTCCGGY

HDNHDTCKCCGGMGA NRRRCAWGTCCDGRCATGYY

$32.90 \%$

$32.90 \%$
$53.89 \%$

$5.75 \%$
$32.50 \%$
$29.50 \%$

NDATGASTCAYN

HACTTCCGGY

RATGASTCAT
VTGACTCATC

DATGASTCAT

GGATGACTCATC

NNATGASTCATH

NATGASTCABNN

GATGASTCATCN

RRCATGYCYRGRCATGYYYN

NNDRCATGYCYNRRCATGYH

ACCGGAAGTG

AVCCGGAAGT

NRYTTCCGGH
RACCGGAAGT

RGCTGAGTCA

TGCTGAGTCA

CCCCGCGC

AAAACCRGWW

NYTAATCCYB

RNNRNCAAGCADNDB

RRAACCRGTTYRAACCRG

GTCATGCHTGRCTGS

GCAGCCAAGCRTGACH

KCCGTNWTTTBCGGC

RGCCGGCYWW

TTTGAAAA

$30.50 \%$

$30.96 \%$

$27.63 \%$
$35.41 \%$

$35.41 \%$

$31.60 \%$
$24.31 \%$

$24.31 \%$
$27.31 \%$

$18.23 \%$

$18.23 \%$

$8.03 \%$

$8.43 \%$

$22.04 \%$
$51.46 \%$

$51.46 \%$
$25.93 \%$

$50.08 \%$

$50.08 \%$

$42.06 \%$
$9.97 \%$

$9.97 \%$
$72.37 \%$

$97.89 \%$

$97.89 \%$
$19.29 \%$

$19.29 \%$

$39.38 \%$

$53.65 \%$

$53.65 \%$

$9.24 \%$

$19.45 \%$

$19.45 \%$

$23.74 \%$

$23.10 \%$

$22.1 \%$
$43.2 \%$

$\begin{array}{ll}10.9 \% & 0.012 \\ 12.5 \% & 0.012\end{array}$

Vagal Ganglia

Motif Name

$\%$ of Target Sequences

with Motif

\begin{tabular}{ccc}
$22.23 \%$ & $10.7 \%$ & $<0.001$ \\
$43.30 \%$ & $10.6 \%$ & $<0.001$ \\
$2.15 \%$ & $3.6 \%$ & $<0.001$ \\
$23.76 \%$ & $8.7 \%$ & $<0.001$ \\
$21.11 \%$ & $8.4 \%$ & $<0.001$ \\
$22.84 \%$ & $8.1 \%$ & $<0.001$ \\
$19.93 \%$ & $7.7 \%$ & $<0.001$ \\
$27.01 \%$ & $8.4 \%$ & $<0.001$ \\
$23.74 \%$ & $7.9 \%$ & $<0.001$ \\
$17.23 \%$ & $7.1 \%$ & $<0.001$ \\
$19.92 \%$ & $7.4 \%$ & $<0.001$ \\
$12.26 \%$ & $6.0 \%$ & $<0.001$ \\
$8.79 \%$ & $5.2 \%$ & $<0.001$ \\
$4.74 \%$ & $3.7 \%$ & $<0.001$ \\
$16.48 \%$ & $5.6 \%$ & $<0.001$ \\
$44.60 \%$ & $6.9 \%$ & $<0.001$ \\
$20.46 \%$ & $5.5 \%$ & $<0.001$ \\
$43.72 \%$ & $6.4 \%$ & $<0.001$ \\
$36.55 \%$ & $5.5 \%$ & 0.002 \\
$7.13 \%$ & $2.8 \%$ & 0.006 \\
$67.54 \%$ & $4.8 \%$ & 0.006 \\
$96.03 \%$ & $1.9 \%$ & 0.008 \\
$15.49 \%$ & $3.8 \%$ & 0.008 \\
$3.19 \%$ & $1.8 \%$ & 0.015 \\
$34.78 \%$ & $4.6 \%$ & 0.015 \\
$49.01 \%$ & $4.6 \%$ & 0.021 \\
$6.80 \%$ & $2.4 \%$ & 0.023 \\
$14.89 \%$ & $3.3 \%$ & 0.024 \\
$16.13 \%$ & $3.3 \%$ & 0.035 \\
$20.19 \%$ & $3.6 \%$ & 0.038 \\
$58.46 \%$ & $4.2 \%$ & 0.045 \\
$19.66 \%$ & $3.4 \%$ & 0.046 \\
of Background & \% Difference & \\
ences with Motif & Target vs. Background & FDR \\
\hline & & \\
\hline & & \\
\hline
\end{tabular}

F0 Veh F2 Base vs F0 Veh F2 Sens

Consensus

$34.68 \%$

$13.0 \%$

$<0.001$

Fo Veh F2 Base vs Fo HDM F2 Base

Elk4(ETS)/Hela-Elk4-ChIP-Seq(GSE31477)/Homer

NRYTTCCGGY

$36.32 \%$

0.005

F0 HDM F2 Base vs F0 HDM F2 Sens

AT3G58630(Trihelix)/col-AT3G58630-DAP-Seq(GS
Elk4(ETS)/Hela-Elk4-ChIP-Seq(GSE31477)/Homer

TCTCCGGCGA

HDNHDTCKCCGGMGA

$6.54 \%$

$51.09 \%$

$21.41 \%$

$42.05 \%$

$8.4 \%$


F0 Veh•F2 Sens vs FO Veh•F2 Base

\section{Metabotropic glutamate receptor group III \\ Platelet derived growth factor signaling}

Cholecystokinin receptor signaling

Ari

\section{Grik3, Grik4, Grm6, Prkar1b, Prkar2b}

Arhgap26, Arhgap27, Fli1, Gab1, Grap2, Prr5

Arhgap15, Elf4, Ephb2, Gm49337, Itpr1, Itpr3, Map2k2, Mtor, Rasal1,

Rps6ka3, Spdef, Stat3, Vav1

Akap1, Camkk1, Chga, Hbegf, Itpr1, Map2k6, Nfkbia, Nos1, Prkg1, Ptk2b, Pxn, Rgs2, Rps6ka3, Ryr1, Slc18a2, Src, Stat3, Tpcn2
7.58

5.05

0.038

Gonadotropin-releasing hormone receptor

Adcy1, Adcyap1, Adipoq, Cacna1c, Cacna1d, Camk2b, Dgkz, Dnm1, Egr1

Gata2, Gnas, Gnb1, Itpr1, Lhx2, Map3k10, Nfatc2, Nos1, Nr4a1, Nr5a1,

Pik3r1, Pitx1, Prkag2, Prkce, Prkcz, Smad1, Smad3, Tcf7

Wnt signaling

Ankrd6, Bc19, Cdh18, Celsr1, Ctbp1, Ctnna1, En1, Fzd1, Fzd5, Gm37388,

Pcdhga12, Pcdhgb2, Ppp2r5c, Prkce, Prkch, Prkcz, Smad1, Tcf7, Tle4, Ttbk1,

Wnt7b, Wnt16 